\title{
19. \\ SPLIT OD TRAVNJA 1941. \\ DO RUJNA 1943. GODINE: \\ MJESTO FAŠISTIČKE REPRESIJE I \\ ANTIFAŠISTIČKOG OTPORA
}

\section{Aleksandar Jakir}

UDK: 94(497.5 Split)“1941/1944“

Pregledni rad

Sažetak: U radu se tematizira fašistička represija i antifašistički otpor u Splitu u razdoblju od travnja 1941. do rujna 1943. godine. Zračnim napadom talijanske avijacije 6. travnja 1941. godine Drugi svjetski rat stigao je u Split. Nakon sloma i okupacije Kraljevine Jugoslavije tzv. Rimski ugovori o određivanju granica između Nezavisne Države Hrvatske (u ugovoru pod „službenim“ nazivom Kraljevina Hrvatska) i Mussolinijeve Italije od 18. svibnja 1941. predviđali su da i „grad Split uključivši predgrađa“ bude dijelom fašističke Italije, odnosno sjedište jedne od triju prefektura unutar provincije pod nazivom Governatorato di Dalmazia (Guvernatorat Dalmacija) pod pokrajinskom upravom (Governo della Dalmazia) u Zadru. Toga proljeća 1941. godine za oko 130000 stanovnika Splitske prefekture, u kojoj se provodila bezobzirna talijanizacija, započelo je zasigurno najtraumatičnije razdoblje 20. stoljeća. Raspoloživi izvori jasno govore o tome da je većina Splićana u svim fazama ratne kataklizme pokazala trajno antifašističko opredjeljenje, o čemu svjedoči i velik broj poginulih boraca i žrtava fašističkog terora u Drugom svjetskom ratu rođenih u Splitu. Bespoštedni rat koji se vodio na području bivše Kraljevine Jugoslavije bio je višeslojan i uključivao je mnoge aktere. Zbivanja u Splitu za toga najkrvavijeg sukoba u ljudskoj povijesti mogu se podijeliti u dva dijela: prvi dio, od početka bombardiranja do kapitulacije Italije 8. rujna 1943., te drugi, od rujna 1943. do listopada 1944. i povlačenja njemačkih i ustaških snaga iz grada. U danima kapitulacije Italije snaga NOP-a u Splitu dostiže vrhunac, o čemu svjedoči razoružanje glavnine divizije „Bergamo“.

Ključne riječi: Split, 1941. - 1943., talijanska okupacija, Splitska prefektura, narodnooslobodilački pokret

D rugi svjetski rat bio je najrazorniji i po broju žrtava najstrašniji do sada zabilježeni međunarodni sukob u povijesti čovječanstva. Dana 1. rujna 1939. godine, napadom Hitlerove Njemačke na Poljsku, započeo je rat koji se vodio na tri kontinenta i na svim svjetskim oceanima, a u kojemu su naposljetku sudjelovale gotovo sve postojeće države. ${ }^{1}$

$1 \quad$ Literatura o Drugom svjetskom ratu obuhvaća vrlo velik broj naslova. Usp. npr. World War II Bibliography, dostupno preko poveznice https://detroithistorical.org/sites/default/files/pdfs/Bibliography.pdf; Rolf-Dieter MüLLER, Der 
Znanstveno utemeljene procjene polaze od toga da je u tom strašnom ratu stradalo više desetaka milijuna ljudi, neki izračuni čak znatno nadmašuju već u biti nepojmljivu i često spominjanu brojku od 50 milijuna žrtava. ${ }^{2}$ Realno je polaziti od toga da je na području jugoslavenske države između 1941. i 1945. godine stradalo više od milijun ljudi. ${ }^{3}$ Doista nije pretjerivanje kad se o tom ratu govori kao o najvećoj katastrofi 20. stoljeća. U Europi ovaj je rat neodvojiv od tzv. Novog poretka ${ }^{4}$ utemeljena na rasističkoj ideologiji nacizma te na teroru Trećeg Reicha i njegovih fašističkih saveznika i satelita. Rat je iza sebe ostavio tragične posljedice i predmet je mnogobrojnih historiografskih istraživanja i rasprava do naših dana. ${ }^{5} \mathrm{U}$ ovom kratkom sintetičkom pregledu bit će riječi o fašističkoj represiji i antifašističkom otporu u Splitu u razdoblju od 1941. do rujna 1943. godine.

Zračnim napadom talijanske avijacije 6. travnja 1941. godine Drugi svjetski rat stigao je u Split. Trajat će sve do konačnog oslobođenja grada 26. listopada 1944. godine. Toga dana crvenim je slovima na prvoj stranici lista Slobodna Dalmacija osvanuo naslov: „OSLOBODJEN JE SPLIT ponos hrvatske Dalmacije“. U prethodne tri i pol godine grad je teško stradao. Dana 3. lipnja 1944. godine bio je metom savezničkog bombardiranja. Tom je prilikom ubijeno 227 civila te nepoznat broj vojnika, a srušeni su i brojni dijelovi grada. Najteže su stradali gradska luka, predgrađe Lučac, ${ }_{2}$ odručje Pazara i brodogradilište. ${ }^{6} \mathrm{Na}-$ kon sloma i okupacije Kraljevine Jugoslavije tzv. Rimski ugovori ${ }^{7}$ o određivanju granica između Nezavisne Države Hrvatske (u ugovoru pod „službenim“ nazivom Kraljevina $\mathrm{Hr}$ vatska) i Mussolinijeve Italije od 18. svibnja 1941. predviđali su da i „grad Split uključivši predgrađa“ bude dijelom fašističke Italije, odnosno sjedište jedne od triju prefektura unutar provincije pod nazivom Governatorato di Dalmazia (Guvernatorat Dalmacija) pod pokrajinskom upravom (Governo della Dalmazia) u Zadru. ${ }^{8}$ U proljeće 1941. godine započelo je

Zweite Weltkrieg, Darmstadt 2015., 161-164; http://enciklopedija.lzmk.hr/clanak.aspx?id=8719; http://www.enciklopedija.hr/natuknica.aspx?ID=59137; http://proleksis.lzmk.hr/18542/.

2 Usp. Michael Clodfelter, Warfare and Armed Conflicts. A Statistical Reference to Casualty and Other Figures, 1500 2000, Jefferson 2002. Usp. i http://www.warchronicle.com/numbers/WWII/deaths.htm; http://wars.findthedata. com/1/54/World-War-II i https://sh.wikipedia.org/wiki/Drugi_svjetski_rat_u_Jugoslaviji\#Gubici.

3 Usp. Vladimir ŽerJavić, Opsesije i megalomanije oko Jasenovca i Bleiburga. Gubici stanovništva Jugoslavije u drugom svjetskom ratu, Zagreb 1992.

4 Usp. Birgit Kletzin, Europa aus Rasse und Raum. Die nationalsozialistische Idee der Neuen Ordnung, 2 sv., Münster 2000. - 2002.; Michael SALEWSKI, „Europa. Idee und Wirklichkeit in der nationalsozialistischen Weltanschauung und Praxis, Europas Mitte (ur. Otmar Franz), Göttingen 1987.; Richard Overy i dr. (ur.), Die „Neuordnung“ Europas. NS-Wirtschaftspolitik in den besetzten Gebieten, Berlin 1997.; Mark Mazower, Hitler's Empire. Nazi Rule in Occupied Europe, London 2008. Usp. i njem. izd. Hitlers Imperium. Europa unter der Herrschaft des Nationalsozialismus, München 2009.

5 Usp. Nikica Barić, Ustaše na Jadranu. Uprava Nezavisne Države Hrvatske u jadranskoj Hrvatskoj nakon kapitulacije Kraljevine Italije, Zagreb 2012.; Francesco CACCAMO - Luciano Monzali (ur.), L'occupazione italiana della Iugoslavia (1941-1943), Firenze 2008.; Ivo Goldstein, Hrvatska povijest, Zagreb 2013.; Nada Kisić-Kolanović, NDH i Italija. Političke veze i diplomatski odnosi, Zagreb 2001.; Bogdan Krizman, Ante Pavelić i ustaše, Zagreb 1978.; Bogdan Krizman, NDH između Hitlera i Mussolinija, Zagreb 1986.; Sibe Kvesić, Dalmacija u Narodnooslobodilačkoj borbi, Zagreb 1960.; Miroslav ĆuRIN (ur.), Split u narodnooslobodilačkoj borbi i socijalističkoj revoluciji 1941.-1945., Split 1981.; usp. dokumente i knjige o Drugom svjetskom ratu na teritoriji Jugoslavije i povezanim zbivanjima dostupni na http://www.znaci.net/.

6 Usp. Duško KečKemet, Prošlost Splita, Split 2002., 236.

7 Aleksandar JAKIR, „Rimski ugovori između NDH i Italije“, Rimski ugovori: Kraljevina Italija - Kraljevina Hrvatska (NDH), 18. svibnja 1941. (ur. Marin Kuzmić i Boris Vušković), Split 2016., 24-53.

8 Kao dobar prikaz najvažnijih zbivanja za vrijeme talijanske okupacije Splita i protagonista talijanske okupacije grada za vrijeme Drugoga svjetskoga rata usp. Marin Pelaić, Split za vrijeme talijanske okupacije (1941. - 1943.), Split 
za oko 130000 stanovnika Splitske prefekture, u kojoj se provodila bezobzirna talijanizacija, zasigurno najtraumatičnije razdoblje 20. stoljeća.

Raspoloživi izvori jasno govore o tome da je većina Splićana u svim fazama ratne kataklizme pokazala trajno antifašističko opredjeljenje, o čemu svjedoči i veliki broj poginulih boraca i žrtava fašističkog terora u Drugom svjetskom ratu rođenih u Splitu. U knjizi $A n-$ tifašistički Split. Ratna kronika 1941. - 1945., ${ }^{9}$ koja donosi detaljnu kronologiju zbivanja u gradu Splitu za vrijeme rata, u predgovoru naslovljenom „Homerski dani Splita grada“, nalazimo podatak da je

(...) od 40-ak tisuća njegovih stanovnika 18.000 građana aktivno surađivalo u NOP-u [Narodnooslobodilačkom pokretu, nap. A. J.]. Od toga je naoružano 12.500 boraca, a kroz splitske zatvore-mučilišta iz grada i okolice prošlo je više od 15.000 rodoljuba. ${ }^{10}$

U masovnost otpora doista teško da može biti osnovane sumnje. Ogromna je, i doima se teško preglednom, količina i raznovrsnost izvora koji svjedoče o ratnim splitskim godinama: od intimnih zapisa i sjećanja pojedinaca, preko službene i poluslužbene građe raznorazne provenijencije i publicističkih tekstova do arhivskih vrela. ${ }^{11}$

U nedavno (ponovno) otkrivenom i u digitalnom obliku objavljenom dnevniku jednog od glavnih ideologa nacionalsocijalizma, Alfreda Rosenberga, ${ }^{12}$ potvrđuje se u njegovim ciničnim formulacijama posvećenima operaciji instaliranja marionetske vlade u Zagrebu (Rosenberg ga, naravno, naziva Agram) u travnju 1941., odnos i namjere nacionalsocijalističkog režima prema ovom dijelu Europe. ${ }^{13}$ Zločinačka politika Hitlerove Njemačke i

2012. Osobita pozornost usmjerena je prema političkom ustroju grada od travnja 1941. do rujna 1943. godine te procesu sustavne dekroatizacije, odnosno talijanizacije i fašizacije grada.

$9 \quad$ Usp. Antifašistički Split. Ratna kronika 1941. - 1945. (ur. Marin Kuzmić i dr.), Split 2010. Pojedina poglavlja uredili su Lovre Reić i Goran Kotur (ožujak - lipanj 1941.), Goran Kotur (srpanj - prosinac 1941. i srpanj - rujan 1943.), Vlasta Višić (siječanj - lipanj 1942.), Gordana Tudor (srpanj - prosinac 1942.), Vjekoslav Vidjak (siječanj - lipanj 1943. i listopad 1943. - svibanj 1945.). Zbog lake dostupnosti ove knjige (kojoj se u digitalnom obliku može pristupiti preko http://www.ratnakronikasplita.com) i vrlo ograničenog prostora ovoga pregleda, ovdje se neće iznositi kronologija događaja. Isto, XIII.

11 Igor Graovac još je početkom 1980-ih godine konstatirao da je istraživanje o sudjelovanju pojedinih društvenih slojeva „naprosto zanemareno“, a to se do danas nije, nažalost promijenilo. Usp. Igor GraOvac, „Pregled sudjelovanja pojedinih grupa stanovništva Splita u NOB-u i socijalističkoj revoluciji 1941. godine“, Split u narodnooslobodilačkoj borbi i socijalističkoj revoluciji 1941.-1945. (ur. Miroslav Ćurin), Split 1981., 361-376. Vojni aspekt puno je bolje dokumentiran. Usp. „1. dalmatinska proleterska brigada: popis boraca iz Dalmacije“, Dalmatinci u Prvoj proleterskoj brigadi. Zbornik sjećanja i popis boraca iz Dalmacije (ur. Miroslav Ćurin), Split 1982.; „1. dalmatinska proleterska brigada: pregled komandira i komesara, spisak boraca", Prva dalmatinska proleterska NOU brigada (ur. Mirko Novović i Stevan Petković), Beograd 1986.; Marijan ŽUlJAN, „2. dalmatinska proleterska brigada: popis boraca“, Druga dalmatinska proleterska brigada (ur. Zdenko Cvrlje), Split 1982.; „4. dalmatinska (splitska) brigada: popis boraca“, u: Mate ŠAlov, Četvrta dalmatinska (splitska) brigada, Split 1980.; „6. dalmatinska udarna brigada: spisak komandnog kadra i poginulih boraca“, u: Danilo Damjanović, Sesta dalmatinska brigada, Beograd 1969.; Narodnooslobodilačka borba u Dalmaciji 1941-1945. Zbornik dokumenata (ur. Vinko Branica), knj. 1, Split 1981.; knj. 2, Split 1982.; knj. 4, Split 1983.; knj. 10, Split 1986.; Zbornik dokumenta i podataka o Narodnooslobodilačkom ratu jugoslovenskih naroda. Tom XII. Dokumenti jedinica, komandi i ustanova Kraljevine Italije (ur. Miloš Krstić), knj. 1, Beograd 1969.; Zbornik dokumenta i podataka o Narodnooslobodilačkom ratu jugoslovenskih naroda. Tom IX. Dokumenti organizacija Komunističke Partije (ur. Fabijan Trgo), knj. 1, Beograd 1961.

12 Usp. Eduard Gugenberger, Boten der Apokalypse. Visionäre des Dritten Reichs, Wien 2002.; Ernst Piper, Alfred Rosenberg. Hitlers Chefideologe, München 2005.; http://www.britannica.com/biography/Alfred-Rosenberg.

13 Faksimil teksta Rosenbergova dnevnika i transkript dostupni putem poveznica https://www.ushmm.org/information/ exhibitions/online-features/special-focus/the-alfred-rosenberg-diary i http://collections.ushmm.org/view/2001.62.14; usp. također Robert K. Wittman - David Kinney, The Devil's Diary. Alfred Rosenberg and the Stolen Secrets of the 
njezinih satelita za vrijeme rata na ovom području u znanstvenoj literaturi dobro je opisana i opće poznata. ${ }^{14}$

O tome, pak, što je rat značio za Split i Dalmaciju saznajemo iz jednog drugog dnevnika. Radi se o dnevniku Lujze Janović-Wagner, istaknute medicinske djelatnice u međuratnom razdoblju i jedne od organizatorica medicinskog sestrinstva u Hrvatskoj. Ona svoj dnevnik započinje u Splitu, u koji se doselila u jesen 1940. godine, riječima:

I tako smo 18. V. 1941. godine doživjeli ponovno da su Hrvati tražili tuđeg gospodara. (...) Mi smo baš pred sedam mjeseci doselili iz Zagreba i sada sjedimo u Spalato, Italija. Raspoloženje je ispod ništice - kod nas u kući, na ulici, u gradu čitavom, pa i u okolici. ${ }^{15}$

Svoj posljednji zapis završava uoči Božića 1944. godine, nekoliko tjedana prije smrti. Lujza Janović-Wagner kraj rata i oslobođenje nije dočekala. Međutim, čitajući njezina zapažanja, odmah uočavamo da su njezini dnevnički zapisi, napisani u obliku pisama mlađem bratu Vlatku i suprugu Špiri u kojima opisuje svoje doživljaje ratnih dana, ne samo štivo kroz koje upoznajemo jednu izuzetnu ženu (neki su je nazivali hrvatskom Florence Nightingale), nego i nadasve koristan povijesni izvor za to razdoblje hrvatske povijesti. ${ }^{16} \mathrm{U}$ obilju izvora od posebne su važnosti autentična svjedočenja o danima rata koja nam govore o ljudskoj svakodnevnici u tom vremenu.

Priređivačica dnevnika, Snježana Grković-Janović, Lujzina kći, u svom predgovoru s punim pravom ističe da je danas malo pisaca dnevnika, ali da postoji obilje memoara koji se pišu nakon što su događaji postali sjećanje. A sjećanje je, među ostalim, izloženo zaboravu, i uvijek možemo (i moramo) postaviti pitanje koliko je vjerodostojno. Vezano za Lujzin dnevnik, priređivačica ističe: „Čitatelj će se uvjeriti da ona ima žarku želju svjedočiti svoju istinu o događajima. Čini nam se kao da čujemo vlastitim ušima i vidimo vlastitim očima zvukove i slike koje je ona slušala i gledala 1941., 1942., 1943. i 1944. godine."17

Third Reich, New York 2016.; Jürgen MatтhäUs - Frank Bajohr, The Political Diary of Alfred Rosenberg and the Onset of the Holocaust, Lanham 2015.

14 Usp. navedenu literaturu u: Aleksandar JAKIR, „Die 7. SS-Freiwilligen-Gebirgs-Division 'Prinz Eugen’ in Dalmatien“", Nationalsozialismus und Regionalbewusstsein im östlichen Europa. Ideologie - Machtausbau - Beharrung (ur. Ingo Loose i Burkhard Olschowsky), München - Berlin 2016., 369-386. Usp. i novije radove Alexandera Korba: Im Schatten des Weltkriegs. Massengewalt der Ustaša gegen Serben, Juden und Roma in Kroatien 1941-1945, Hamburg 2013.; „Understanding Ustaša Violence“, Journal of Genocide Research, 12/2010., br. 1-2; 1-18; „Nation-building and mass violence: The Independent State of Croatia, 1941-45",The Routledge History of the Holocaust (ur. Jonathan C. Friedman), New York 2011., 291-302.

15 Snježana Grković-Janović (prir.), Lujzin dnevnik. Dnevnički zapisi Lujze Janović-Wagner iz Drugog svjetskog rata, Zagreb 2008., 25. Lujza Janović-Wagner došla je iz Zagreba u Split 1940. godine s mužem (dr. Špirom Janovićem) i djecom nakon mnogih godina aktivnog sestrinskog rada. Tu je dočekala početak rata, a kasnije seli s obitelji na Brač u obiteljsku kuću Janovića u Sumartinu na Braču. U ljeto 1944. godine vratila se s djecom u Zagreb (supruga nije vidjela od 1943., kada je otišao $s$ partizanima na Vis), ali ni u roditeljskom domu nije pronašla mir jer su je pratili zbog povezanosti s partizanima. Tjedan dana nakon 38. rođendana od ustaškog Redarstva dobiva poziv da se javi „radi saslušanja“. Pet dana provodi u zatvorskoj ćeliji s još dvije učiteljice i jednom služavkom, a šesti dan puštena je bez ikakvog ispitivanja. No, vratila se kući zaražena pjegavim tifusom i umrla je 17. veljače 1945. godine.

7 Isto, 16. Čini mi se točnom tvrdnja da su dnevnici koji nastaju bez distance uglavnom bliže istini jer pisac dnevnika obično nema puno vremena za dotjerivanje i interpretacije te pokušava svjedočiti svoju istinu o događajima koje opisuje. To pogotovo vrijedi za vođenje dnevnika u ratnim uvjetima u kojima je Lujza Janović-Wagner pisala svoje zabilješke, a njezina tragična smrt prije završetka rata današnjem čitatelju omogućavaju upoznavanje perspektive autorice koja je bilježila svoje dojmove bez znanja o tome kako će rat završiti. 


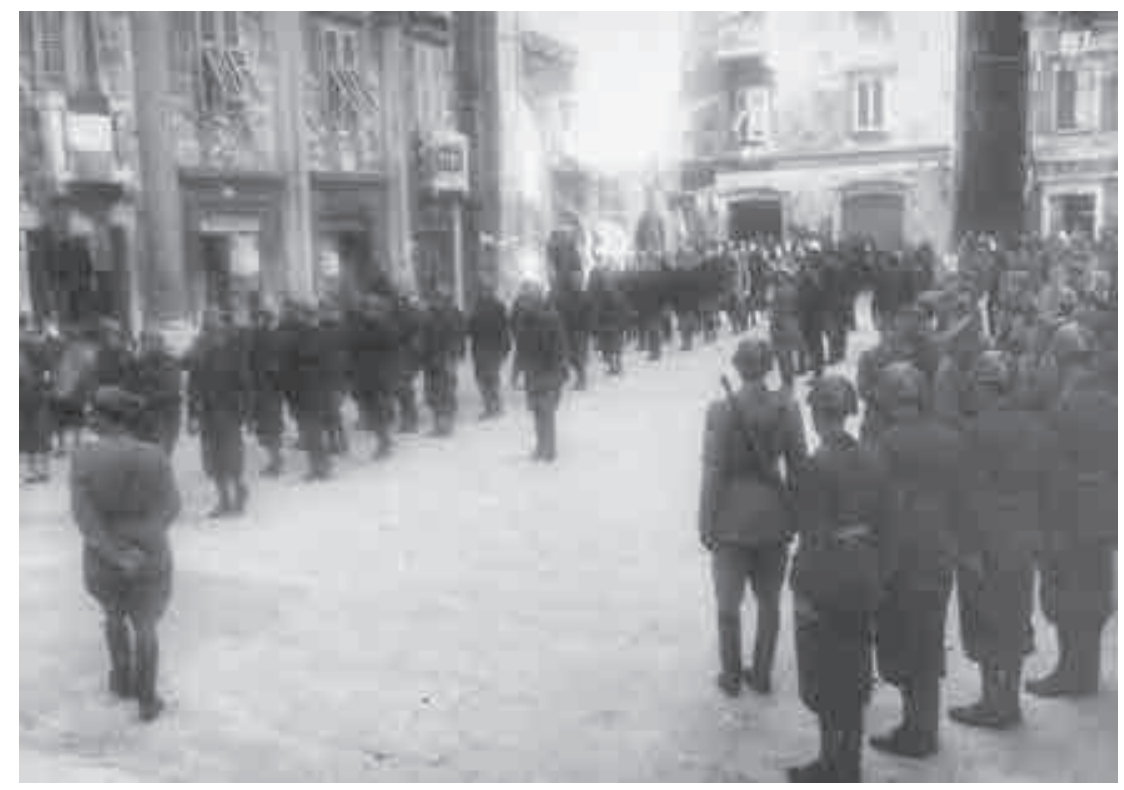

Sl. 1. Proslava dvadesete godišnjice fašističke ere u Splitu (Muzej grada Splita)

U ratu koji je započeo 6. travnja 1941. napadom nacističke Njemačke i fašističke Italije na Kraljevinu Jugoslaviju, koja je za desetak dana, tj. već 17. travnja, kapitulirala, dijelove Kraljevine Jugoslavije okupirale su njemačka, talijanska, bugarska i mađarska vojska. Uz okupaciju uspostavljeni su kvislinški režimi u Hrvatskoj (pod Antom Pavelićem) i u Srbiji (pod Milanom Nedićem). Dolaskom talijanske vlasti u Split 1941. Lujza započinje svoj dnevnik pišući prvu od 265 stranica u debelu trgovačku knjigu tvrdog uveza u koju je njezin otac do svoje smrti bio zapisivao troškove podizanja, odgoja, školovanja, izlazaka svoje djece. Lujzin dnevnik pruža nam uvid kako je ova mlada žena - medicinska sestra koja je stekla široku naobrazbu i govorila više stranih jezika i koju je rat zatekao s njezinom djecom u Splitu i na Braču - proživljavala opću tragediju Drugoga svjetskog rata u Dalmaciji. Zapisi svjedoče o ljudskim sudbinama te o tome kako su se obični ljudi u tim preteškim vremenima nosili s izazovima rata. Radi se o autentičnom svjedočanstvu o jednom vremenu, a možemo ga iščitati i kao obavijest o neuljepšanim osjećajima, nazorima i nadama u određenom povijesnom trenutku.

Čitajući Lujzin dnevnik, snažan dojam ostavlja spoznaja da njezina istina o ljudima o kojima zapisuje svoja razmišljanja nije crno-bijela. Naime, ne susrećemo heroje, idealizirane borce za slobodu (kako ih se prečesto glorificirajući prikazivalo u socijalističkom razdoblju nakon 1945.), a među njemačkim dočasnicima i običnim vojnicima, koji se spominju u dnevniku, možemo prepoznati katkad i dobre i suosjećajne ljude. Tako je opisan i slučaj njemačkog narednika Willya Brabanta, komandanta Sumartina na Braču, koji je pokušavao hraniti i liječiti civile i štititi uhićene, zbog čega su ga njegovi nadređeni kažnjavali, što se, dakako, ne uklapa u pojednostavljene predodžbe i narative. Opisujući partizane, koje Lujza doživljava kao „naše“, ona se ne libi zapisivati ljutite, gorke opomene i kritike zbog nekih njihovih nerazumnih i nepotrebno okrutnih djela. Sredinom srpnja 1944. go- 
dine zapisuje kako se „bunila zbog neopravdanih, glupavih i nepravednih poruka iz šume“ te nastavlja: „Morala sam braniti sebe od Nijemaca kao i od poganih jezika žena kod nas i u Selcima. ${ }^{\text {"18 }}$ No, prijatelje je birala prema njihovim ljudskim kvalitetama i djelima ne gledajući na odoru koju mnogi nisu dobrovoljno odabrali. Janović-Wagner naglašava: „U čitavom životu Splita i Brača proveli smo [njezin suprug Špiro i ona, nap. A. J.], a kasnije ja sama, princip da si ne dam nipošto i nikako skučiti moju ličnu slobodu i da si biram društvo tamo gdje hoću i koga hoću. Moj rad [medicinske sestre] pak pokazuje tko sam i što sam. ${ }^{\text {"19 }}$ Pod datumom 20. siječnja 1944. Lujza zapisuje: „Rat je u Sumartinu. Ono što smo htjele izbjeći, nismo, evo, niti ovdje mogli. “20

Njezini dnevnički zapisi potresno svjedoče o ljudskoj patnji u vrtlogu rata; nalazimo precizna zapažanja, „kako je sve tužno i strašno i ružno“, a pitanje, kako je zabilježila, „naše i njihovo", misleći pritom na svoje sumještane u Sumartinu kojima je kao medicinska sestra pomagala, ali ne zaboravljajući ni brojne njemačke vojnike koje je upoznala na Braču, glasi: „Zar ne može bit drukčije?" ${ }^{21}$ Lik autorice dnevnika, ali i mnogi u njemu opisani, potvrđuju da se i pod najtežim uvjetima - kad je naizgled sve „tužno i strašno i ružno“22 - moglo ostati čovjekom. Životni krug Lujze Janović-Wagner zatvorio se u dvorani zgrade Škole narodnog zdravlja u Zagrebu, gdje je započela svoj sestrinski rad i gdje su joj u veljači 1945. godine suradnici i medicinske sestre odali posljednju počast.

Kako njezina zapažanja, kako život i smrt autorice uklopiti u našu predodžbu o ratu? Nedvojbeno su o svim temama vezanima za Drugi svjetski rat od 1945. pa naovamo napisane biblioteke, a literatura nastala prošlih desetljeća o povijesnim zbivanjima i problemima vezanim za povijest i prošlost ovog dijela Europe pruža nam širok spektar mogućih interpretacija. Opće je poznato da se interpretacije i metode povijesnog istraživanja s vremenom mijenjaju. Svaki reflektirani pristup mora voditi računa o primijenjenoj historiografskoj metodi u cilju dobivanja validnih znanstvenih rezultata. Svjedočanstva su uvijek dragocjen izvor, ali ne smijemo zaboraviti na nužno subjektivan karakter te vrste izvora. Puno je svjedočanstava različitih vrsta otpora koje su Splićani i Splićanke pružali za vrijeme talijanske i njemačke okupacije. Ako danas i raspravljamo o dvoznačnosti ili višeznačnosti antifašizma kao opreci fašizmu i nacionalsocijalizmu, najgorim režimima u ljudskoj povijesti, moramo se istovremeno zapitati što je u ondašnjim uvjetima rata i okupacije bila alternativa borbi protiv nacističke Njemačke i ostalih fašističkih država i pobjedi nad njima?

$S$ druge strane, čini se besmislenim negiranje činjenice da je oslobođenje svijeta od jedva zamisliva nacifašističkoga barbarstva istovremeno značilo i savezništvo is totalitarnom staljinističkom diktaturom i s onima koji su u njoj gledali svoj politički uzor i ideal te koji su u ime revolucije i diktature proletarijata bili spremni upotrijebiti sva sredstva (a žrtve nisu žalili) da do revolucije i dođe. Nije li utemeljeno primijetiti, kao što to čine pojedini povjesničari, da antifašizam nije samostojeća ideja upravo zato što je bio pokret "protiv“ i da su

\footnotetext{
18 Isto, 99.

19 Isto.

20 Isto, 61.

21 Isto, 63.

22 Isto.
} 
ideju antifašizma podržavali ljudi raznih svjetonazora i uvjerenja: liberali i konzervativci, socijalisti i komunisti, anarhisti i katolici? Sve to možemo prepoznati i na mikrorazini, na primjeru Splita: na lokalnoj razini, razumije se, nije bilo samo antifašista nego i simpatizera, pa i gorljivih pristaša fašizma.

Antifašizam je u svojim počecima bio povezan $s$ otporom liberalnih intelektualaca, poput Benedetta Crocea i Giovannija Amendole, protiv Mussolinijeva režima. Jedan od istaknutih antifašista u tom smislu bio je i Splićanin Bogdan Radica. Njegovo je antifašističko djelovanje tijekom Drugoga svjetskog rada u SAD-u premalo poznato, a upravo je on igrao važnu ulogu u pridobivanju američke javnosti u procesu promjene američke politike prema narodnooslobodilačkom pokretu pod vodstvom Josipa Broza Tita. ${ }^{23}$ Nakon talijanske okupacije Splita i Dalmacije 1941. godine antifašizam je u praksi imao više oblika.

U svemu nipošto ne bismo trebali zaboraviti što su ideologija i praksa fašizma i nacionalsocijalizma značili, pa tako i u Splitu za vrijeme okupacije. Otpor protiv takve zločinačke ideologije i prakse onih hrabrih žena i muškarca koji su se oduprli kad je nacistička Njemačka ovladala gotovo cijelom kontinentalnom Europom i kad nije bilo izvjesno kako će se ta borba završiti, nedvojbeno zaslužuje biti istaknut kao glavna značajka tih ratnih godina.

Bespoštedni rat koji se vodio na području bivše Kraljevine Jugoslavije bio je višeslojan i uključivao je mnoge aktere. ${ }^{24}$ Kad je još za travanjskoga rata 1941. Komunistička partija Jugoslavije formirala svoj Vojni komitet na čelu s Josipom Brozom Titom i kad je 15. travnja CK KPJ uputio „Proglas narodima Jugoslavije“ u kojemu ih poziva da „ne klonu duhom“, već da ustraju u borbi protiv osvajača, jugoslavenski su komunisti krenuli u rat. Njihova je koncepcija bila da mnoštvom lokalnih ustanaka rasplamsaju sveopći rat protiv okupatora i domaćih pomagača. Pokrajinski komitet Komunističke partije Hrvatske za Dalmaciju izdao je 22. travnja 1941. godine proglas u kojem je pozvao narod na jedinstvo u borbi protiv okupatora. Činjenica je da su to počeci onoga što je kasnije nazvano Narodnooslobodilačkom borbom U Hrvatskoj su istaknuti komunisti - Rade Končar, Andrija Hebrang, Vlado Popović, Vladimir Bakarić i Ivan Rukavina - prionuli organiziranju ustanka računajući na čvrstu jezgru discipliniranog članstva Komunističke partije te pozivajući narod na borbu protiv okupatora i obranu domovine, što je i u Dalmaciji naišlo na masovni odaziv. Kao što je poznato, hrvatski partizani bili su ključni za NOVJ, a do kraja 1943. Hrvatska, s 24\% jugoslavenskog stanovništva, davala je više partizana nego Srbija, Crna Gora, Slovenija i Makedonija zajedno, a prema nekim procjenama Dalmacija je do kraja rata dala više desetaka tisuća partizanskih boraca (što, dakako, uključuje i mobilizirane borce nakon pada Italije u rujnu 1943.). ${ }^{25}$

Valja se prisjetiti da je 22. lipnja 1941., na dan napada Hitlerove Njemačke na Sovjetski Savez s ciljem osvajanja „životnog prostora na istoku“ (Lebensraum im Osten), kad je po-

23 Usp. Bogdan Radica, Agonija Evrope. Razgovori i susreti, Beograd 1940. (hrv. izd. Agonija Europe. Razgovori i susreti, Zagreb 2006.); Stevo ĐurašKović, „Zaboravljeni hrvatski kozmopolit Bogdan Radica“, Dijalog povjesničara - istoričara 10 (ur. Hans-Georg Fleck i Igor Graovac), sv. 1, Zagreb 2007., 307-327.

24 Usp. Jozo Tomasevich, Rat i revolucija u Jugoslaviji 1941-1945. Okupacija i kolaboracija, Zagreb 2010.

25 Usp.https://hr.wikipedia.org/wiki/Narodnooslobodila\%C4\%8Dka_vojska_i_partizanski_odredi_Jugoslavije\#cite_ note-Cohen_95-30 i tamo navedenu literaturu. 
krenuta zastrašujuća vojna sila od oko 3,8 milijuna ljudi, u šumi Žabno (Brezovici) pokraj Siska formiran Prvi sisački partizanski odred sa 79 boraca pod zapovjednikom člana KPH Vladom Janićem Capom. Taj odred bio je prvi takav organiziran način pružanja oružanog otpora u Europi.

Početkom kolovoza 1941. iz Zagreba u Dalmaciju stižu delegati Centralnog komiteta KPH Pavle Pap Šilja i Mirko Kovačević. Njihov je zadatak bio ubrzati prelazak s diverzantskih akcija na oružani ustanak. Na sastanku Pokrajinskog komiteta KPH za Dalmaciju, održanom 7. kolovoza 1941., odlučeno je da se u roku od tri dana formira sedam partizanskih odreda i da ih se prebaci u Liku i Bosnu. Od 8. do 14. kolovoza 1941. osnovani su tako Splitski, Šibenski, Vodičko-zatonski, Primoštensko-krapanjski, Solinski, Trogirski i Sinjski partizanski odred. Pokrajinski komitet za Dalmaciju, na čelu sa Vickom Krstulovićem, ${ }^{26}$ 11. kolovoza 1941. godine upućuje Prvi splitski partizanski odred, tri voda po 22 borca, iz Splita prema zaleđu. Međutim, već trećeg dana, 14. kolovoza, kod sela Košute nadomak Trilja, neiskusni borci upadaju u talijansko-ustašku zasjedu. Odmah u početku bitke poginuo je zapovjednik odreda Mirko Kovačević Lala. Jedan dio boraca uspio se spasiti, a drugi dio bio je zarobljen. Svi su zarobljenici sprovedeni u Sinj, gdje je dvadeset i jedan od dvadeset i četiri splitskih mladića nakon kratkog suđenja odlukom ustaškog „Priekog pokretnog suda" proglašen krivim. Zajedno s njima strijeljana su i dva borca Solinskog partizanskog odreda, Ante Katić i Ante Čerina, te seljak Šimun Stojanac iz Dicma, optužen da je dostavljao oružje partizanima. Strijeljani su 26. kolovoza 1941. godine na predjelu Ruduša kraj Sinja. ${ }^{27}$

Poznato je da je za vrijeme Drugog svjetskog rata, zbog različitih koncepcija o ustanku na području Dalmacije, Vicko Krstulović dolazio u sukobe s osobama koje su po partijskoj hijerarhiji bile na višim položajima od njega. ${ }^{28}$ Nakon razlaza između njega i Josipa Broza Tita, u listopadu 1943., Pokrajinski komitet KPH za Dalmaciju preimenovan je u Oblasni komitet KPH za Dalmaciju. Svejedno će nakon kapitulacije Italije Krstulović biti jedan od glavnih aktera prilikom akcije zauzimanja Splita. S Ivom Lolom Ribarom otišao je 10. rujna 1943. u Split na pregovore Narodnooslobodilačkog odbora Splita s talijanskim zapovjednicima, koji su talijanskog generala Emilia Becuzzia, zapovjednika divizije „Bergamo“, doveli do toga da preda Split i oružje.

26 Vicko Krstulović, Memoari jugoslovenskog revolucionera, tom 1: Na stazama partije, revolucije i bratstva i jedinstva. 1905-1943., Beograd - Sarajevo - Zagreb 2012.

27 Usp. Nikola Anić, Antifašistička Hrvatska. Narodnooslobodilačka vojska i partizanski odredi Hrvatske 1941.-1945., Zagreb 2005. Imena strijeljanih boraca Prvoga splitskog partizanskog odreda su: Đordano Borovčić Kurir, Franin (komandir Odreda); Alfred Santini, Šimunov (politički komesar); Ivan Antonini, pok. Stipana; Nebojša Borozan, pok. Ivana; Mirko Dujmić, pok. Stipana; Branko Duplančić, Lukin; Dušan-Duško Frua, pok. Eurika; Petar Jelaska, Antin; Jozo-Josip Krstulović, Marinov; Jozo-Josip Markotić, pok. Ljubomira; Ivan Markotić, pok. Grge; Marin Matković, pok. Ivana; Vjekoslav-Vjeko Ozretić, Ivanov; Josip-Jozo Petrić, Dujin; Ante Popović, pok. Kristina; Josip Radetić, pok. Duje; Dragutin Rogulj, pok. Ivana; Tadija Skopljanac, Markov; Ante Torkar, Josipov; Davor Urlić, pok. Fausta; Ante Zelić, pok. Jure.

28 Krstulović je od 1940. bio jedan od sedam članova Centralnog komiteta KPJ koji su dolazili iz Hrvatske (J. Blažević, V. Janić, R. Končar, J. Kraš, V. Krstulović, M. Orešković i S. Romac). Jedino više tijelo od CK bio je njegov Politbiro, u koji je iz Hrvatske izabran jedino Končar (J. Broz Tito, E. Kardelj, A. Ranković, M. Đilas, F. Leskošek, I. Milutinović). Usp. Ivan Jelić, Komunistička partija Hrvatske 1937-1941, Zagreb 1972., 320. 
Antifašistički oružani ustanak pod vodstvom KPJ u Dalmaciji započinje paralelno s ustankom u zapadnoj Bosni i Lici. Pripremama za oružani ustanak rukovodio je Pokrajinski komitet Komunističke partije Hrvatske za Dalmaciju. U svjetlu dostupne literature čini se razumnim pretpostaviti da su još za vrijeme rata u travnju 1941. komunistički simpatizeri započeli sa skupljanjem i skrivanjem oružja i municije. Tada po nalogu KPJ u Dalmaciju dolazi Marko Orešković, član Centralnog komiteta KP Hrvatske i KP Jugoslavije, sa svojim ratnim iskustvom iz Španjolskog građanskog rata. Orešković je bio na funkciji političkog komesara najprije Grupe Narodnooslobodilačkih partizanskih odreda za Liku, a potom Glavnog štaba NOP odreda Hrvatske. Zajedno s Pokrajinskim komitetom KPH formira Vojnu komisiju, a kasnije i vojne komisije pri okružnim, kotarskim i gradskim komitetima. Te komisije stvorile su prve udarne grupe koje su do početka ustanka vršile diverzije i sabotaže u sjevernoj i srednjoj Dalmaciji.

U srpnju 1941. izbila je pobuna srpskog stanovništva na teritoriju NDH, što je dovelo do žestoke političke borbe između KP i srpskih političkih grupacija za pridobivanje masa za suprotne političke programe i ciljeve. Na početku pobune borbe su vođene zajedno, ali to nije dugo trajalo. Četnički centar za Hrvatsku osnovan je već u svibnju 1941., i to u Splitu, što je talijanska vlast tolerirala. ${ }^{29}$ Već krajem ljeta splitski četnički centar povezao se s Dragoljubom (Dražom) Mihailovićem u Srbiji i stavio pod njegovo zapovjedništvo. Krajem listopada osnovana su u okolini Knina dva četnička puka i nekoliko odreda, zatim početkom 1942. zloglasna Dinarska četnička divizija, koja je počinila mnoge zločine nad civilnim stanovništvom Dalmacije. Zapovjednici su bili četničke vojvode Ilija TrifunovićBirčanin i Momčilo Đujić. Potonji je bio pravoslavni pop. ${ }^{30}$ Prema podacima koje četnički vojvoda Birčanin iznosi u izvještaju Draži Mihailoviću Dinarska čentička divizija imala je u svom sastavu 5 pukova i 2 odreda, iz čega se može iščitati kako je sredinom 1942. ta divizija imala oko 4400 pripadnika. ${ }^{31}$ Organiziranjem tzv. dobrovoljačkih protukomunističkih formacija (Milizia volontaria anticommunista, MVAC), oružanih protukomunističkih skupina, u talijanskoj okupacijskoj zoni kolaboracija četnika s Talijanima, kao i s državnim tijelima NDH, postaje bjelodana. ${ }^{32}$

Međutim, oružani antifašistički otpor na početku rata doživljava bolne poraze. Naime, kao što se to dogodilo Prvom splitskom partizanskom odredu, zbog nedovoljnih priprema i slabe organizacije prebacivanja, gotovo svi odredi bili su razbijeni ili su prestali postojati.

29 Četnici lojalni Draži Mihailoviću tijekom Drugoga svjetskog rata u Dalmaciji su mogli računati na podršku jednog malog broja Hrvata koji su se u međuratnom razdoblju izjašnjavali kao integralni Jugoslaveni, tj. jugoslavenski nacionalisti (npr. književnici Niko Bartulović i Đuro Vilović) i malobrojnih pristaša predratnog Jugoslavenskog narodnog pokreta Zbor.

30 Fikreta Jelić-Butić, Četnici u Hravtskoj 1941-1945, Zagreb 1986.; Jozo Tomasevich, Četnici u Drugom svjetskom ratu, Zagreb 1979. Poznat je programski dokument četničkoga pokreta pod imenom „Elaborat Dinarske divizije“, u kojem je navedeno da je ta divizija osnova i uporište za širenje četničkoga pokreta u sjevernoj Dalmaciji, Lici i dijelovima $\mathrm{BiH}$.

31 Fikreta Jelić-Butić posebno naglašava kako su Birčaninovi podaci utemeljeni na planovima regrutacije i mobilizacije u stanovništvu, koji de facto nikad nisu u potpunosti provedeni u djelo. Usp. F. Jelić-Butić, Četnici u Hravtskoj, 94-95.

32 Isto, 107. 
Smatra se da je jedan od glavnih razloga ovog neuspjeha bio što su u početku ustankom rukovodili ljudi koji nisu dobro poznavali lokalnu situaciju na terenu, poput Papa i Kovačevića. Novi se odredi ponovno osnivaju tek krajem 1941. godine. ${ }^{33}$

Zbivanja u Splitu, za vrijeme toga najkrvavijeg sukoba u ljudskoj povijesti, mogu se podijeliti u dva dijela: prvi dio, od početka bombardiranja do kapitulacije Italije 8. rujna 1943., te onaj od rujna 1943. do listopada 1944. i povlačenja njemačkih i ustaških snaga iz grada. U historiografiji za vrijeme SFRJ često je isticano da su „gradski centri, posebno radnička klasa, imali (...) veoma značajnu ulogu naročito u pripremnoj i početnoj etapi NOB-a, kada su ti centri bili glavni izvor ljudskih i materijalnih potencijala narodnooslobodilačke borbe. Split je bio najznačajnije uporište KPH u Dalmaciji, u kome je u godinama prije rata izrastao snažan revolucionarno-demokratski pokret. ${ }^{\text {“34 }}$ Ondašnja historiografija razlikovala je „nekoliko osnovnih etapa“:

1. Pripremni period (april - juli 1941); 2. Otpor okupatoru u raznim oblicima, pokretanje oružane borbe i prenošenje njezinog težišta izvan gradskog područja (august 1941 - proljeće 1942); 3. Period do kapitulacije Italije i oslobođenje Splita (proljeće 1942 - septembar 1943); 4. Period njemačke okupacije do oslobođenja (27. septembra 1943 - 26. oktobra 1944)..$^{35}$

Činjenica je da su od prve oružane akcije u gradu Splitu 14. rujna do 9. studenoga 1941. (posljednja oružana akcija - bacanje bombi na talijansku vojnu muziku) izvršene 24 oružane akcije u koordinaciji Komunističke partije. Međutim, brzo se došlo do zaključka da akcije u gradovima „po svom učinku, nisu bile u razmjeru s gubicima partijskih kadrova i žrtvama nanesenim odmazdom okupatora i kvislinga (u Splitu je od juna do sredine novembra 1941. jedna trećina članova Partije uhapšena, strijeljana ili internirana)“. ${ }^{36}$

Talijanske vojska ušla je u Split 15. travnja 1941., a u suočavanju s naglim procesom talijanizacije i fašizacije dolazi do vrlo različitih reakcija. Kao što se to može iščitati iz raspoloživih izvora, postoje primjeri splitskih Talijana koji su potpomagali otpor okupatoru, ali i splitskih Hrvata koji su surađivali s novim vlastima. U nedavno objavljenoj publikaciji Split za vrijeme talijanske okupacije (1941. - 1943.) Marina Pelaića, nastaloj temeljem istraživanja izvora i literature, uvjerljivo je opisano, među ostalim, djelovanje fašističke vlasti u Splitu, čije su istaknute ličnosti bile civilni komesar općine Split Antonio Tacconi te vicefederal fašističke Federacije u Splitskoj provinciji Giovanni Savo, Splićanin „od kolina“ iliti „fetivi“.37

33 Usp. Početak oružanog ustanka 1941., dostupno preko poveznice https://sh.wikipedia.org/wiki/Dalmacija_u_ Narodnooslobodila\%C4\%8Dkoj_borbi.

34 Usp. Fabijan TrGO, „Split kao grad u realizaciji koncepcije općenarodnog oslobodilačkog rata“, Split u narodnooslobodilačkoj borbi i socijalističkoj revoluciji 1941.-1945. (ur. Miroslav Ćurin), Split 1981., 479-480.

35 Trgo navodi da je Split uoči travanjskog rata „sa svojih 140 članova Partije i preko 200 skojevaca i velikim brojem aktivista (...) potvrdio svoje demokratsko i patriotsko raspoloženje“ te da je ukupno gledano „učešće građana Splita u NOB-u - u oružanoj borbi i svim drugim oblicima aktivne borbe i otpora - predstavljalo, po karakteru i sveobuhvatnosti, izraziti primjer punog ostvarenja načela svenarodnog rata“. Isto, 490.

36 Isto, 486.

37 Usp. Marin Pelaić, Split za vrijeme talijanske okupacije (1941. - 1943.), Split 2012., bilješka 8. Posebna poglavlja posvećena su ustroju talijanske vlasti te brojnih fašističkih društava, brutalnoj represiji koje je fašistička vlast vršila nad stanovništvom, od prijetnji i zabrana do torture i smaknuća, ali i različitim oblicima otpora koje su građani pružali 
$\mathrm{Na}$ narednim stranicama poslužit ću se primarno rezultatima istraživanja Marina Pelaića da bih dao pregled najvažnijih aspekata za vrijeme talijanske okupacije Splita.

Potpuno utemeljenom se čini ocjena kako je svakodnevni život Splićana u tom razdoblju bio određen drakonskim zakonima novih fašističkih vlasti koji su, između ostalog, doveli do toga da je većina građana postupno osiromašila te na koncu gladovala. Također se čini nedvojbenim da je u Splitu u danima kad je u Zagrebu proglašena Nezavisna Država Hrvatska vladao kaos. Jedini koji su znali što hoće bili su komunisti, koji su oduzeli oružje dobrom dijelu vojnika jugoslavenske vojske i pozivali na otpor, te frankovci, koji su u ime NDH zaposjeli zgrade općine, banovine i pošte. Dana 15. travnja u Split stiže dr. Edo Bulat, ustaški ministar za Dalmaciju (koji je, u vremenu dok se Splitu u jugoslavenskim novinama tepalo kao „najjugoslavenskijim gradom“, bio pripadnik Organizaci-

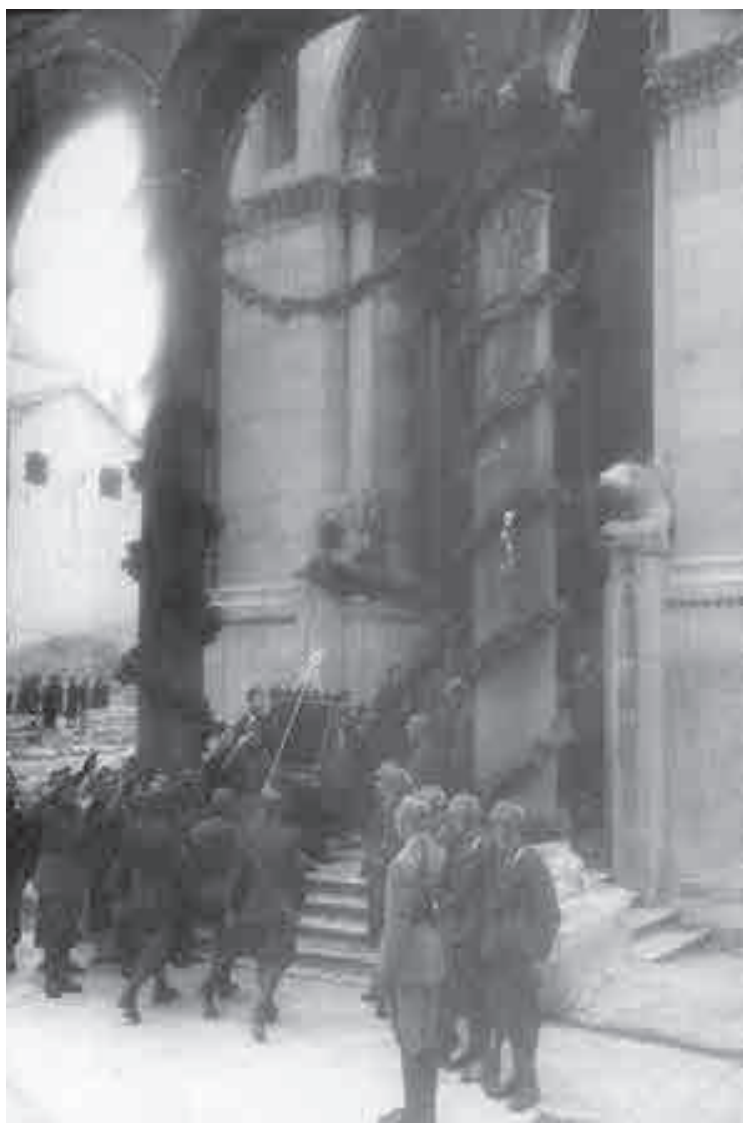

Sl. 2. Proslava dvadesete godišnjice fašističke ere u splitskoj katedrali (Muzej grada Splita)

je jugoslovenskih nacionalista, zloglasne ORJUNE). Bulat stiže kao ustaški ministar s dijelom njemačke vojske, a onodobne novine i sjećanja govore o tome da su ih građani Splita u velikom broju pozdravljali cvijećem i hrvatskim zastavama dok se kolona kretala Solinskom cestom, vjerujući da će upravo oni preuzeti vlast u Splitu kao što se to ranije dogodilo u Zagrebu. No, istoga dana u poslijepodnevnim satima u Split su istom cestom stigle jedinice motoriziranog korpusa II. armije talijanske vojske. Građani su na njihov dolazak uglavnom ostali pasivni. Predsjednik HSS-a Vladko Maček pozvao je Hrvate već 10. travnja da surađuju s novom vlašću. S druge strane, kao što je rečeno, Pokrajinski je komitet KPH za Dalmaciju tjedan dana nakon talijanske okupacije Splita (22. travnja) izdao proglas u kojem je pozvao narod Dalmacije da zbije redove i suprotstavi se okupatoru.

Nedugo nakon potpisivanja Rimskih ugovora, Civilni je komesarijat za dalmatinske provincije ukinut, a uspostavljeno je Namjesništvo za Dalmaciju (Governo della Dalma- 
zia). Funkciju namjesnika, tj. guvernera, obnašao je Giuseppe Bastianini, koji je provodio politiku središnje vlasti iz Rima, za što je izravno odgovarao Mussoliniju. ${ }^{38}$ Nakon odlaska Bastianinija funkciju Namjesnika preuzima Francesco Giunta, koji je nastavio voditi politiku sličnu Bastianinijevoj. Namjesništvo će biti ukinuto 7. kolovoza 1943. godine, a prefekture podređene Ministarstvu unutarnjih poslova. Teritorij anektirane Dalmacije podijeljen je na provincije. Uz već postojeću Zadarsku, oformljene su Splitska (7. lipnja 1941.) i Kotorska provincija.

Glavnu riječ u provincijama imali su prefekti, a splitski prefekt od početka okupacije pa sve do kraja kolovoza 1943. godine bit će zloglasni dr. Paolo Zerbino. ${ }^{39}$ Apsolutnu političku vlast i moć u Splitu imala je Nacionalna fašistička stranka (Partito Nazionale Fascista - PNF), a osnovna organizacija stranke bila je fascio..$^{40}$ Splitski fascio osnovan je 19. rujna 1941. godine sa sjedištem u palači Vitturi. U prvom elitnom odredu (1. squadra) zapovjednik je bio Giovanni Savo, a zamjenik Antonio Hoffmann. Polazi se od toga da je u travnju 1943. godine u Splitu bilo 1310 fašista, od čega 29 skvadrista. Ženske fašističke organizacije imale su ukupno 557 članica, Fašistička sveučilišna mladež (GUF - Gioventu Universitaria Fascista) 225 članova, a Talijanska liktorska mladež (GIL - Gioventu Italiana del Littorio) sa sjedištem u bivšem Sokolskom domu 5444 člana. ${ }^{41}$ Pelaić, međutim, oprav-

38 M. Pelaić, Split za vrijeme talijanske okupacije, 371. Bastianini je rođen 8. ožujka 1899. godine u Perugi. Kako navodi Pelaić, jedan je od začetnika i vođa fašističkog pokreta u rodnom gradu i pokrajini Umbriji. Ući će u parlament 1924., a od 1927. godine kao diplomat radit će u Maroku, Portugalu i Grčkoj. Od 1936. do 1939. bio je podtajnik u talijanskom Ministarstvu vanjskih poslova te posljednji talijanski ambasador u Londonu prije nego je Italija Velikoj Britaniji objavila rat. Bit će imenovan Namjesnikom Dalmacije 21. svibnja 1941., a glavni zadatak bio je eliminirati ili makar ograničiti ma kakav slavenski utjecaj u toj regiji. Osim antislavenskog, karakterizirao ga je i jak antisemitski osjećaj. Suočen s jakim otporom stanovništva, zatražio je dolazak crnokošuljaša iz Lombardije i Toskane. Upravo on stoji iza većine naredbi o odmazdi nad civilima kao što su strijeljanja te oduzimanja živežnih namirnica. Odgovoran je i za logor na Molatu, gdje je do polovice 1942. godine po njegovu priznanju internirano oko 2000 obitelji. U veljači 1943. Mussolini je sebe postavio na funkciju ministra vanjskih poslova, a kao svog podtajnika htio je upravo Bastianinija te je ovaj 7. veljače napustio Zadar i funkciju dalmatinskog namjesnika. Na zasjedanju Velikog fašističkog vijeća 24. srpnja 1943. glasao je protiv Mussolinija. Nakon kapitulacije Italije pobjegao je u Švicarsku. Godine 1959. vratio se u Milano i napisao knjigu Volevo fermare Mussolini (Htio sam zaustaviti Mussolinija). U knjizi, ako je vjerovati Lucianu Monzaliju, Bastianini pokušava opravdati svoje brojne postupke za vrijeme fašističke vladavine, a razdoblje koje je proveo u Zadru kao Namjesnik Dalmacije ne spominje ni jednom riječju.

39 Isto, 355. Zerbino je rođen 21. lipnja 1905. godine u mjestu Carpeneto u pokrajini Piemonte. Pridružio se fašističkom pokretu od njegovih početaka te je, između ostalog, sudjelovao i u Pohodu na Rim. U Split je stigao 16. lipnja 1941. godine, a istog je dana imenovan prefektom Splitske prefekture. Ta funkcija donijela mu je u Splitu hijerarhijski najvišu titulu i najveće ovlasti, što je itekako koristio želeći u što kraćem roku talijanizirati grad. Bio je vrlo sklon izdavanju naredbi za vandalske, često ničim izazvane akcije crnokošuljaša, a u nekima je i sam sudjelovao. Osobno je nadzirao slanje ljudi u zatvore i logore i svojom se efikasnošću u tim poslova hvalio namjesniku Bastianiniju. Kao što to navodi Pelaić, kada su saveznički zrakoplovi počeli nadlijetati Split, među prvima je organizirao bijeg s obitelji. Iz Splita je pobjegao noseći sa sobom sve dragocjene umjetnine koje je uzeo za svoju rezidenciju iz Galerije umjetnina. U Italiji će se priključiti Mussolinijevoj Talijanskoj Socijalnoj Republici (Repubblica Sociale Italiana), gdje će obnašati funkciju ministra unutarnjih poslova. S Duceom će ostati do posljednjih trenutaka. Talijanski partizani uhitit će ih u Dongu, a potom 28. travnja 1945. i strijeljati.

40 Isto, 70. Borbeni fascio (Fascio di combattimento) sastajao se od osam odreda (squadra), a svaki je odred brojao po deset članova uključujući zapovjednika i njegova zamjenika. Na nižoj razini mogle su se organizirati pojedine područne skupine, sekcije i odredi. Rad fascia sjedinjavala je Federazione dei fasci di combattimento. Na čelu Federacije bio je federalni tajnik, a federacije su ustrojavane na razini provincija.

41 Isto, 71. Provincijski Direktorij činili su vicefederali Giovanni Savo i Aurelio Bonavia te Giuseppe Mallardo, Silvio Maurano, Bonaventura Foretich, Angelo Bareris i Luigi Carancini. Dakako, postojale su i brojne fašističke organizacije za žene i mlade, kao što su Fascio femminile (ženski fascio), GIL - Gioventu Italiana del Littorio (Talijanska liktorska mladež sa sjedištem u bivšem u Sokolskom domu) i GUF - Gioventu Universitaria Fascista (Fašistička sveu- 
dano upozorava da ovi brojevi ne pokazuju realno stanje jer je na mladiće i djevojke vršen konstantan pritisak da se učlane u neku od ovih organizacija, a odluci o učlanjivanju svakako je kumovalo i to što su fašisti imali prednost pri podjeli hrane i ostalih potrepština, baš kao i veće šanse za zapošljavanje.

Izvanredni sud za Dalmaciju (Tribunale Straordinario della Dalmazia) činili su predsjednik i dva suca, a funkciju državnog tužitelja vršio je jedan oficir Vojne i Dobrovoljne milicije javne sigurnosti (MVSN). Ako se „dokaže da je optuženi kriv za djela za koja za tereti, kazna je smrt“. ${ }^{42}$ Od 18. veljače 1942. u Dalmaciji se počinju primjenjivati Ustav i drugi temeljni zakoni Kraljevine Italije. ${ }^{43}$ Krajem godine prefekt Zerbino izdaje podčinjenim tijelima u Splitu naredbu za formiranje Centra za prikupljanje i obuku građana provincije Split u jedinice Antikomunističke milicije (MVAC) koja će u sastavu divizije Zara djelovati protiv partizana.

Metode nadziranja građana i prevencija eventualnog neposluha bile su upotrebljavane za cijelo vrijeme okupacije. Jedna od njih bilo je konstantno legitimiranje stanovništva, $s$ tim da se nisu priznavale jugoslavenske legitimacije, već samo one koje je izdala splitska kvestura (tzv. legitimazione personale). Morale su ih imati sve osobe starije od 14 godina.

Sve bolja organiziranost i veća brojnost partizanskog pokreta u Dalmaciji te iskrcavanje saveznika na Siciliju dovele su do kraha civilnog i vojnog ustroja fašističke vlasti u Splitu. Sedmi dan kolovoza 1943. godine iz Splita je parobrodom redovite pruge Split - Trst otputovalo oko 400 talijanskih činovnika, namještenika i njihovih obitelji. Funkciju prefekta početkom rujna umjesto dr. Paola Zerbina preuzeo je dr. Giuseppe Grimaldi.

O stavu gradske, ali i cjelokupne talijanske vlasti u Splitu možda najbolje svjedoči izjava prefekta Zerbina: „U pet godina neće biti ni jednog Hrvata! A glede Hrvatske, mi smo je stvorili, mi je financiramo i ona će postojati dok bude nas volja!“44 Jedan od prvih poteza povučenih na ovom planu bilo je ukidanje lista Novo doba, koji je naslijedio dvojezični San Marco. Ukidanjem Novog doba, jedinih splitskih hrvatskih novina, ostala je samo Katolička riječ, koja se tiskala na hrvatskom jeziku. Između 3. i 12. studenog 1941. godine demontiran je i na komade rastavljen spomenik Grguru Ninskom na Peristilu, što se također može smatrati udarom na hrvatski identitet Splita. Početkom 1942. u cijeloj okupiranoj Dalmaciji nije se mogao pronaći kalendar na hrvatskom jeziku. ${ }^{45}$

Ukinuvši list Novo doba 23. travnja 1941. godine, Talijani su šest dana kasnije pokrenuli dnevne novine San Marco, objavljivane na hrvatskom i talijanskom jeziku. Uredničke pros-

čilišna mladež). Sindikalna organizacija zvala se OND - Opera Nazionale Dopolavoro. Bila je to organizacija tjelesne i duhovne rekreacije u slobodnom vremenu, koja se u fašističkoj Italiji provodila od 1925. do kraja Drugog svjetskog rata, $s$ ciljem fašističke indoktrinacije posrednim institucionalnim okupljanjem masa.

$42 I s t o, 130$. Taj će sud kasnije biti preimenovan u Tribunale Speciale, a u Splitu će opet djelovati od 18. do 31. ožujka 1943. godine. Istog je mjeseca (listopad 1941.) osnovan Prvi fašistički odred Dobrovoljne milicije za nacionalnu sigurnost (Milizia Volontaria per la Sigurezza Nazionale - MVSN). Policijski komesar Kvesture Split postao je fašist Vincio Vincenzo, a po dolasku fašističkog bataljuna Crnih košulja M (Mussolini), ustrojena je splitska Milizia Volontaria. Splitski karabinjeri i Crne košulje (Camicie nere) ustrojeni su još početkom lipnja.

43 Antifašistički Split, 204.

44 Isto, 105.

45 Isto, 184 
torije, tiskara, papir, pa i suradnici, preuzeti su od Novog doba. Glavni i odgovorni urednik bio je Zadranin Antonio Just-Verdus. Početkom svibnja 1941. u listu San Marco objavljene su naredbe svim uredima i službenicima koje glase:

1) Svi su državni službenici dužni upotrebljavati rimski, tj. fašistički pozdrav. 2) Talijansku zastavu mora usvojiti cijelo pučanstvo. 3) Slike jugoslavenskih ličnosti treba ukloniti i umjesto njih svuda postaviti sliku kralja Italije i vođe fašista Mussolinija. 4) Sve ustanove, javne i privatne, dužne su usvojiti dvojezičnu administraciju. ${ }^{46}$

San Marco je prestao izlaziti krajem studenog 1941. godine, a naslijedio ga Il Popolo di Spalato (glavni i odgovorni urednik Silvio Maurano), koji će izlaziti do 10. rujna 1943., i do tog trenutka uz Gradsku knjižnicu, biti jedan od najvećih i najjačih izvora fašističke propagande u Splitu.

Odmah po uspostavi nove vlasti počeo se primjenjivati Zakon o prezimenima, koji je u Istri postojao od kraja 1923. Njime je, naime, djeci bila zabranjeno davati „smiješna“ netalijanska imena. ${ }^{47}$ Prezimena su se morala pisati talijanskim pravopisom, bez korištenja slova $\check{c}, \dot{c}, \check{s}, d \mathrm{i} \check{z}$, dok su se vlastita imena prevodila (npr. Ljubica je postala Violeta, Mladen - Giovenale, Vjera - Fede, Slavko - Glorio i dr.). Od sredine svibnja 1942. osmrtnice su se smjele objavljivati samo na dvama jezicima, od kojih je prvi uvijek morao biti talijanski. ${ }^{48}$ Naredbom namjesnika Bastianinija od 15. lipnja 1941. godine zabranjen je rad svim kulturnim, sportskim i netalijanskim društvima na području anektiranog dijela Dalmacije, što je uključivalo i rad Hrvatskog nogometnog kluba Hajduk, čije je igralište dobilo ime Campo sportivo Bruno Mussolini u čast poginulog Mussolinijeva sina.

Škole su zauzimale posebno mjesto u procesu talijanizacije jer su u njima trebale biti odgojene generacije na kojima će fašizam i talijanska vlast u Splitu počivati u budućnosti. Pri Ministarstvu za prosvjetu u Rimu otvoren je poseban ured za škole na anektiranom području. ${ }^{49}$ Prvo su provjeravani profesori koji su morali dokazati da su „arijevci“ i obećati da se neće baviti politikom, baš kao ni njihovi učenici, koje su u suprotnom bili dužni prijaviti. Odlučeno je da će se nastava u potpunosti odvijati na talijanskom jeziku te da se na satovima povijesti Dalmaciju treba prikazivati kao iskonsku talijansku pokrajinu koja se oduvijek borila protiv „barbarskog slavenstva“. ${ }^{50} \mathrm{U}$ tu su svrhu organizirani tečajevi talijanskog jezika i književnosti za hrvatske učitelje, a stečeno se znanje provjeravalo usmenim i pismenim ispitima, koje su brojni znali bojkotirati ili namjerno padati. Krajem 1941. godine vlasti u Split dovode veći broj učitelja i profesora iz Italije koji nisu znali ni riječi hrvatskoga jezika. Znajući da ovakva mjera neće imati pozitivan odjek među građanima, gradska je vlast odredila da se svim učenicima koji pohađaju talijanske škole svakodnevno dijele ručak i večera, a učenik koji bude upisan u talijansku školu do Božića 1941. dobit će i zimsko odijelo. Nadalje, učenicima i studentima hrvatske nacionalnosti nuđene su i brojne

\footnotetext{
Isto, 53.

47 Duško VečErina, Talijanski iredentizam, Zagreb 2001., 47.

48 J. Markovina, Sistem talijanske fašističke vlasti u Splitu, 530.

9 Isto, 549.

50 Antifašistički Split, 124.
} 
stipendije za studiranje na talijanskim sveučilištima. Posebnu ulogu u talijanizaciji školstva imao je prefekt Zerbino. On je povremeno posjećivao razne škole kako bi provjerio koliko dobro su učenici ovladali talijanskim jezikom.

Kao što je navedeno, Pokrajinski komitet KPH za Dalmaciju izdao je 22. travnja 1941. godine proglas u kojem poziva narod na jedinstvo u borbi protiv okupatora. Već za Praznik rada te godine na padinama Kozjaka pojavljuju se svjetleće parole „Živio 1. Maj“. Slične će akcije biti poduzimane i na godišnjice Oktobarske revolucije. Na blagdan Svetoga Duje (7. svibnja) te godine pod Marjanom je formiran 1. udarni odred od 63 ljudi. Zakletva koju su tom prigodom položili glasila je: „U ime naroda zaklinjem se da ću se boriti protiv fašističkog okupatora i njihovih sluga za slobodu svoga naroda i dati sve svoje snage, ako ustreba i život." ${ }^{\text {"51 }}$

U prosincu 1941. ponovno je formiran Splitski partizanski odred, ovoga puta od tek 15 boraca. Početkom 1942. partijska je organizacija imala četiri „rajona“: Varoš, Dobri, Manuš i Bačvice. U to vrijeme KPJ u Splitu broji stotinjak članova. Dana 6. travnja 1942. osnovan je Narodnooslobodilački odbor Splita. S obzirom na to da se NOP-u ljeti 1942. pridružio pozamašan broj ljudi, 4. rujna je formirana Prva dalmatinska udarna brigada u koju su ušli Prvi i Drugi bataljun Srednjodalmatinskog partizanskog odreda. U siječnju 1943. splitski NOO, koji je nosio naziv „Luka Botić“, briše to ime iz naziva jer im je preko Okružnoga komiteta KPH rečeno da nikakva tijela vlasti ne nose posebne nazive. U veljači Vrhovni štab NOV i POJ traži da NOO Dalmacije mobilizira sve muškarace od 18 do 30 godina. ${ }^{52}$

Kako je otpor protiv okupatora jačao, mjere prevencije i kažnjavanja otpora bivale su brutalnije. Dana 11. listopada 1941. formiran je Izvanredni sud za Dalmaciju (Tribunale straordinario della Dalmazia). Njegova je svrha bila da se strijeljanjima antifašista dade legalna forma. Već dva dana po osnutku (13. listopada 1941.) taj će sud na smrt osuditi 17 antifašista. Za vrijeme njegovih zasjedanja u Splitu list Il Popolo di Spalato javno je huškao sudske dužnosnike da ignoriraju norme međunarodnog prava kako bi se što efikasnije obračunali s neprijateljem. Nakon napada na povorku talijanske glazbe 9. studenog 1941. u samom gradskom središtu uhićeno je 300 - 600 ljudi, među kojima i neki viđeniji Splićani, pripadnici predratnih političkih stranaka i direktori gimnazija. Većina je odvedena u koncentracijski logor u Divuljama. Postupalo se u skladu s Mussolinijevom naredbom da se za svakog ranjenog Talijana strijeljaju dvojica Hrvata, a za svakog ubijenog dvadeset. ${ }^{53}$ Naravno, ovakvo postupanje s civilnim stanovništvom nije imalo za svrhu samo zaustaviti i spriječiti pobunu, nego se dio netalijanskog puka ovim mjerama htjelo natjerati na odlazak $s$ anektiranog područja. Krajem godine iz Splita je u Italiju otplovio prvi brod sa zatvorenicima koji su bili deportirani u talijanske koncentracijske logore. Iz izvještaja Kraljevske prefekture Splita od 15. svibnja 1942. doznajemo da je sa splitskog područja u razdoblju od 1. listopada 1941. pa do 15. svibnja 1942. u Italiju internirano 1448 osoba, od čega 305 komunista, 48 politički opasnih i 1095 Židova, a na dalmatinske je otoke internirano 118

\footnotetext{
Isto, 52 .

52 Isto, 349.

53 Isto, 154
} 


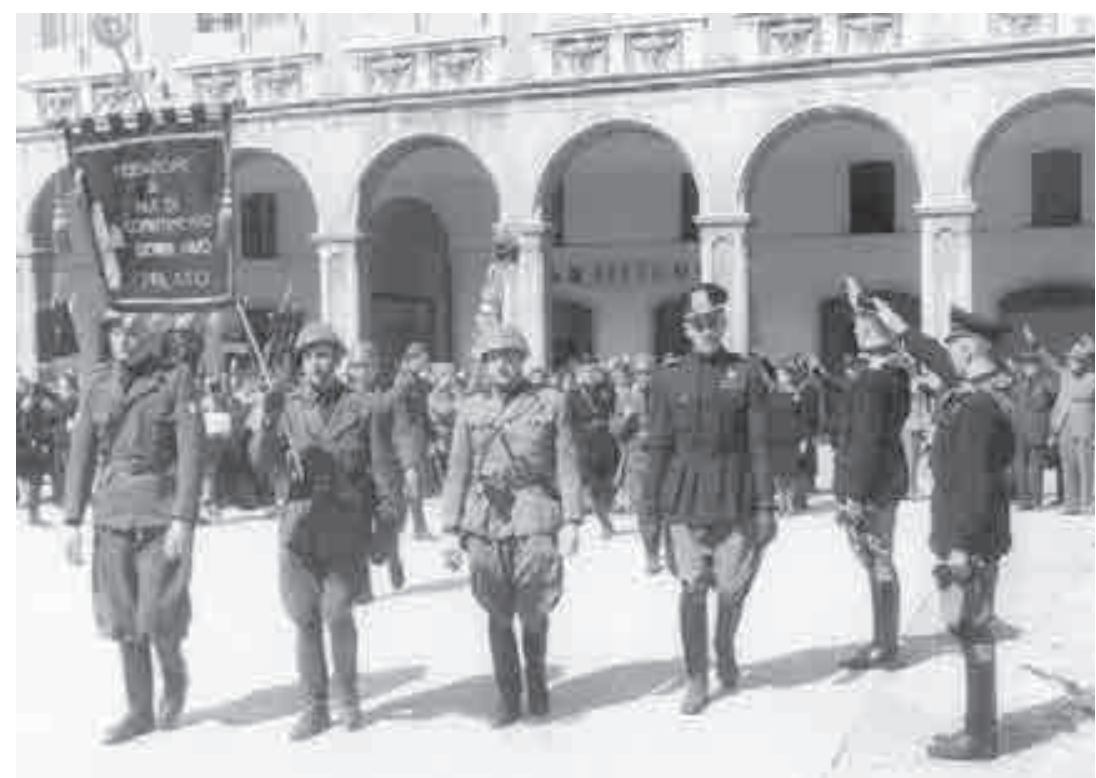

Sl. 3. Komemoracija za fašista Giovannija Savu na Prokurativama. Savo je 18. ožujka 1943. podlegao ranama zadobivenim u atentatu. Šesnaestogodišnji izvršitelj atentata Ante Čerina strijeljan je krajem travnja iste godine. (Muzej grada Splita)

Židova. ${ }^{54}$ Tijekom srpnja 1942. godine na Molat je, uz blagoslov namjesnika Bastianinija, internirano oko 2000 obitelji. Osim onih čiji su se članovi pridružili NOP-u, bilo je tu i onih koji su se tamo našli zbog pjevanja „krivih“ pjesama, pohvalnog komentiranja sabotaža ili, ako se tako procijenilo, zbog slabog zalaganja na radnom mjestu. Stopa smrtnosti bila je vrlo visoka, pogotovo djece. ${ }^{55}$ Građanima se prijetilo zatvaranjem u logore ako su negodovali zbog nedostatka hrane. U napadu bijesa zbog ubojstva viđenog splitskog fašista Antonija Hoffmanna prefekt Zerbino je rekao kako će, bude li potrebno, u 24 sata raseliti svih 54000 Splićana. ${ }^{56}$

Teror okupacije zorno se može prikazati na primjeru postupanja protiv Ćire Gamulina, profesora Muške realne gimnazije. On je, naime, 15. travnja 1942., dakle na godišnjicu proslave ulaska talijanskih trupa u Split, vidjevši djecu kako se igraju u školskom dvorištu, prokomentirao kako bi na današnji dan trebali plakati, a ne smijati se. Jedan od učenika te je riječi prenio svojim roditeljima, a oni Kvesturi. Iste je večeri u stan obitelji Gamulin provalila talijanska patrola. Vođeni bijesom zbog uspješnog bojkota parade povodom navedene godišnjice, vojnici pretražuju stan i pronalaze bilježnicu sastavljenu od neupotrijebljenih listova matematičkih zadaća. Na njoj je stajao natpis „Zapisnik društva Pivac“. Naime, budući da su zbog policijskog sata dobar dio dana morali provoditi u kući, Ćiro, njegova supruga i devetogodišnji sin osnovali su društvo Pivac. Mali Stjepko bio je predsjednik, Ćiro je bio tajnik, a njegova supruga blagajnica. U navedenu bilježnicu zapisivali su rezultate

\footnotetext{
54 Isto, 234.

55 Luciano Monzali, Antonio Tacconi e la comunita’ italiana di Spalato, Venezia 2007., 371.

56 Antifašistički Split, 187.
} 


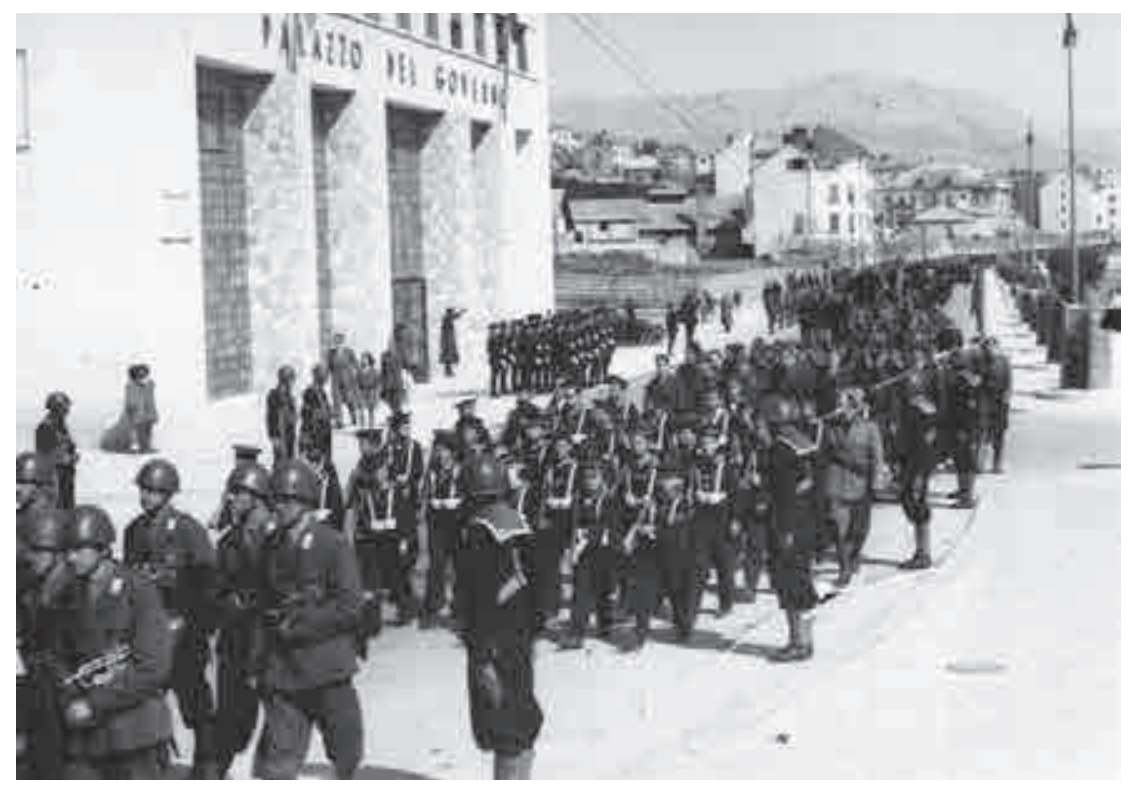

Sl. 4. Pogrebna povorka za fašista Giovannija Savu. Nakon atentata uslijedila je odmazda fašističkih vlasti. (Muzej grada Splita)

postignute u društvenim igrama kojima su kratili vrijeme. Talijani su ustvrdili da je riječ o šifriranom materijalu koji dokazuje povezanost s komunistima i odveli profesora Gamulina u Kvesturu na ispitivanje. Tijekom ispitivanja su ga nemilo tukli. Vrhunac iživljavanja bio je kada ga je jedan crnokošuljaš udario stolicom po leđima tako jako da mu je slomio kralježnicu. Mrtvo tijelo Talijani su odvukli u zahod i razglasili da je umro od kapi za vrijeme istrage. Bilo je to 17. travnja 1942. Njegovoj supruzi i djetetu nije bilo dopušteno da vide tijelo, nije bilo osmrtnice, pogreb nije održan, tek je naknadno pokopan u obiteljskoj grobnici, ali bez ikakve pratnje. Učenici su mu odali počast trima minutama šutnje. Tamo gdje je profesor komentirao godišnjicu proslave ulaska talijanskih trupa u Split, šutjelo se i po 15 minuta. Do početka devedesetih jedna je splitska gimnazija nosila njegovo ime, a o našem vremenu govori sramotna i žalosna činjenica što isto ime ne nosi i danas.

Gradska vlast je za vrijeme okupacije velik trud uložila u zastrašivanje onih koji su se priključili NOP-u. Oni u čijem bi se stanu tijekom pretresa pronašlo vatreno oružje, bili su strijeljani na mjestu, baš kao i oni koji su posjedovali bilo kakve propagandne materijale. Smrtna se kazna predviđala i za sve sudionike sabotaža, diverzija, oružanih akcija i drugih oblika aktivnosti pripadnika NOP-a. Vlasti su u identificiranju antifašista imali pomoć agenata. Jedan od njih, Ivan Gale, glumio je da od građana skuplja priloge za borce te tako doznavao imena barem dijela onih koji simpatiziraju partizanski pokret. Prefekt Zerbino nudio je nagradu od 10 do 50 tisuća lira onima koji prijave imena „rušitelja javnog reda u gradu“. .7 Pomoć u ovome naumu zatražio je i od pravoslavnog svećenika Sergija Urukala, koji će vrbovati mladiće da se pridruže odredima popa Đujića, te splitskog biskupa 


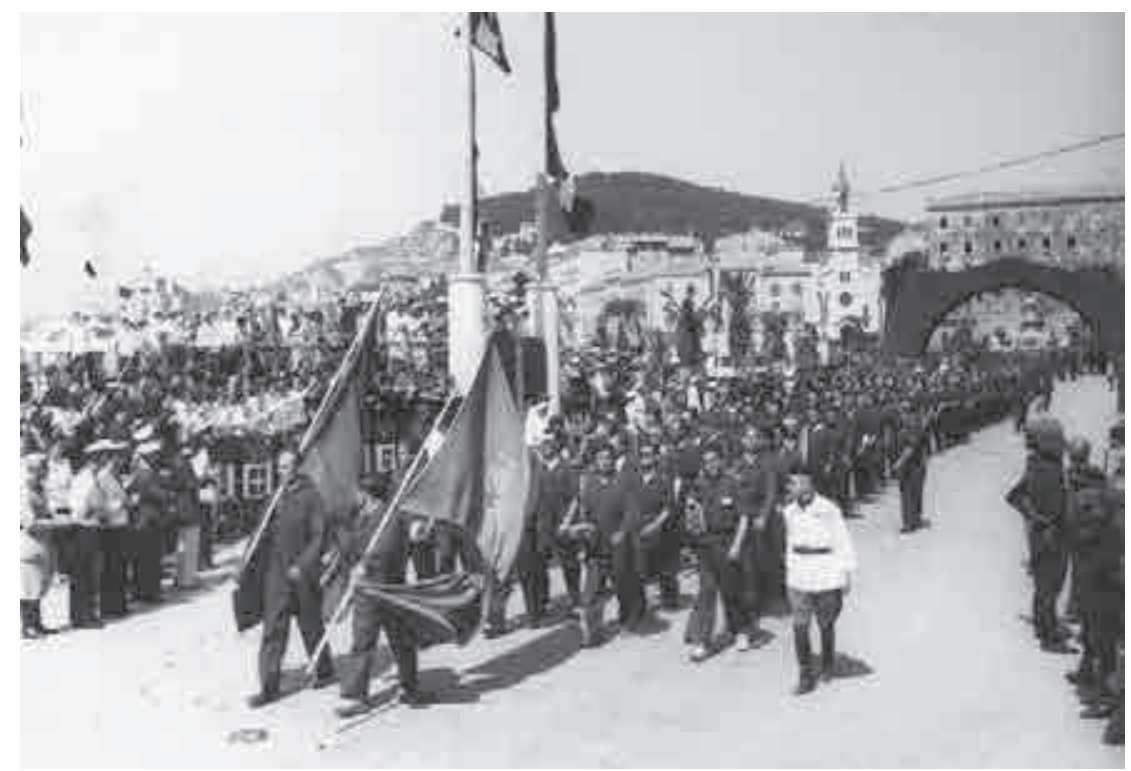

Sl. 5. Masovne parade kao privid uspješnosti fašističkog režima: povorka radnika splitskog i trogirskog brodogradilišta (Muzej grada Splita)

dr. Kvirina Klementa Bonefačića. Biskup je vjernicima uputio tzv. pastirsko pismo kojim ih je pozvao na lojalnost talijanskoj vlasti te na razotkrivanje imena antifašista osuđujući njihove postupke. Građani su se oglušili na ovaj sramotni apel, masovno napuštajući svetu misu za vrijeme čitanja ovog pisma. ${ }^{58}$ Dana 7. lipnja 1942. namjesnik Bastianini pozvao je partizane rođene u Dalmaciji da se vrate kućama do 22. lipnja i prijave karabinjerima, inače će poduzeti represivne mjere protiv njihovih obitelji. Budući da poziv nije imao odjeka, 28. lipnja se započelo $s$ hapšenjima članova partizanskih obitelji i njihovom internacijom na Molat. U rujnu i studenome iste godine splitska Kraljevska kvestura dostavila je kvestorima Rijeke, Pule, Kotora, Ljubljane, Gorice i Trsta popis od oko 200 Splićana koji su se pridružili partizanima. Krajem prosinca nekim obiteljima stiže naredba da napuste anektirano područje u roku od 24 sata zbog djelovanja njihove maloljetne djece na liniji NOP-a. Hapšeni su i trgovci za koje se ispostavilo da su slali novac partizanima. Namjesništvo Dalmacije želi posvaditi partizane s pukom, stoga donosi odluku da se za svaki odrezani ili oboreni stup na mjestu strijeljaju tri taoca (s tim da se broj strijeljanih može povećati u razmjeru s veličinom štete), a sela, krajevi i gradovi uzduž oštećenih linija liše živežnih namirnica. ${ }^{59}$

Prema talijanskoj evidenciji kroz splitske zatvore prošlo je više od 15000 ljudi ${ }^{60}$ Bilo je raznih akcija otpora i diverzije. Među poznatijima je zasigurno ona izvedena 1. svibnja 1942. godine, kad se sa zvonika svetog Duje zavijorila sedam metara duga crvena zastava. 
Otpor talijanizaciji i fašizmu zasigurno ne bi uspio da u njemu nisu sudjelovali Splićani svih slojeva i zanimanja.

Vijest o bezuvjetnoj kapitulaciji Italije 8. rujna 1943. godine, koja se Splitom proširila oko 20 sati, izvela je građane na ulice i nastao je kaos sličan onome iz travnja 1941. godine. Kapitulaciju fašističke Italije Splićani su dočekali s ushićenjem. Odmah se krenulo s razoružavanjem talijanskih vojnika koji su gladni i obezglavljeni lutali gradom. Neki su fašisti u bijegu podmetnuli požar u policijskom uredu i zatvorima te u Općini i Palazzo del Governo kako bi uništili dokumente koji bi ih mogli kompromitirati. Za to vrijeme predsjednik Narodnooslobodilačkog odbora Split, dr. Josip Smodlaka, u hotelu Park dogovarao je primopredaju vlasti s generalom Emiliom Becuzzijem, zapovjednikom divizije „Bergamo“, koji se vodio naredbom generala Spiga da vlast preda Nijemcima. Becuzzi će vlast predati 12. rujna. U Splitu je tada bilo oko 15000 talijanskih vojnika. Oni su predali sve oružje i municiju, bezuvjetno kapituliravši pred najviše 500 vojnika narodnooslobodilačkih snaga. ${ }^{61} \mathrm{U}$ danima kapitulacije Italije snaga NOP-a u Splitu dostiže vrhunac, o čemu svjedoči razoružanje glavnine divizije „Bergamo“. NOO proglašava mobilizaciju svih muškaraca između 17 i 45 godina, a Talijani formiraju talijansku partizansku diviziju „Garibaldi“ od 350 ljudi, koja će sljedećih tjedana sudjelovati u obrani grada. Zatvorenici su pušteni na slobodu, a građani su, unatoč njemačkim bombardiranjima, okitili grad hrvatskim i crvenim zastavama. No, partizani će u Splitu ostati tek nešto više od dva tjedna, a već 27 . rujna SS divizija „Prinz Eugen“, s 92. motoriziranim grenadirskim pukom, zauzet će Split. Njemačka jedinica, pod rukovodstvom kapetana Steinera, pobila je toga dana 63 osobe, uhićene prethodnog dana kod sela Mravinaca. ${ }^{62}$ Nijemci odmah počinju s deportacijama splitskih Židova u logore, a pred crkvom sv. Frane na Rivi podižu vješala. Posljednju židovsku trgovinu u gradu, knjižaru Morpurgo, Nijemci zatvaraju 6. listopada 1943., čime je viševjekovna židovska zajednica izbrisana iz javnog života Splita.

Ako se u današnjoj historiografiji više i ne govori o tome da je stanovništvo Splita tih „septembarskih dana 1943. ispisalo jednu od najsvjetlijih stranica historije svoga slobodarskog grada", ${ }^{63}$ ipak ostaje činjenica da je oslobođenje Splita, dalmatinskih otoka i obale svojevremeno snažno odjeknulo u savezničim krugovima i diljem okupirane Europa, a osobito se, naravno, odrazilo među pripadnicima i simpatizerima NOP-a.

Danas zasigurno ne bismo više upotrijebili formulacije tipične za historiografiju iz vremena socijalizma da su događaji u rujnu 1943. u Splitu ubrzali „definitivan poraz reakcionarnog četničko-mačekovskog bloka (tzv. 'predstavnika građanstva')“, no svejedno je teško i danas osporiti tvrdnju da je upravo tada doista došlo do poraza snaga koje su podržavali stari poredak. Računa se da je prilikom oslobođenja Splita u jugoslavensku vojsku stupilo oko 7000 novih boraca. Ukupno se polazi od toga da je za cijelo vrijeme rata u tzv. NOV stupilo preko 12000 boraca, od toga preko 1100 žena, što znači da se svaki četvrti Splićanin borio s puškom u ruci. U ljeto 1944. broj aktivista NOP-a u Splitu doseže 15 000, od

\footnotetext{
Isto, 535 .

62 Isto, 533.

63 Usp. F. Trgo, „Split kao grad u realizaciji koncepcije općenarodnog oslobodilačkog rata“, 488.
} 
čega najviše žena i omladine, što znači da je svaki treći stanovnik bio na neki način uključen u NOP. ${ }^{64}$

Kad je 8. rujna u popodnevnim satima objavljeno da je između Italije i saveznika sklopljeno primirje, NOO Splita izdao je proglas upućen talijanskim vojnicima u kojemu se govori o tome da su „njemački fašisti sada naši zajednički neprijatelji“:

Mi vas pozivamo, da otpočnemo borbu protiv njemačkih fašista u bratskoj zajednici s nama! (...) Svi u borbu, sve za borbu! Živjela slobodna i demokratska Italija! Živjela slobodna i demokratska Hrvatska! Živjela slobodna i demokratska Jugoslavija! Smrt njemačkim fašistima! ${ }^{65}$

Kratkotrajno preuzimanje vlasti u Splitu dalo je golem poticaj stvaranju novih organa vlasti, među kojima su narodnooslobodilački odbori, kao civilni organi vlasti kojima su pripadali svi normativni i izvršni poslovi osim onih u nadležnosti vojnih vlasti, igrali osobito važnu ulogu. U danima prvog oslobođenja Splita u gradu je dijelovao Gradski NOO, osnovan već početkom travnja 1942. Stvaralo se nešto novo, a režim NDH za Splićane nije predstavljao prihvatljivu alternativu. ${ }^{66}$

Uspjeh partizanskog pokreta u Splitu i Dalmaciji možemo tumačiti kao posljedicu nemilosrdnog odnosa okupacijskih režima prema civilnom stanovništvu, a popularnosti NOB-a sigurno je i doprinijelo široko rašireno siromaštvo i neumorno isticanje demokratskih parola i federalnog načela u organizaciji buduće Jugoslavije, što se mnogima učinilo privlačnim, kao i inzistiranje antifašističkog pokreta, što je posebnu ulogu igralo u Splitu, na beskompromisnoj borbi protiv talijanskog iredentizma.

64 Isto, 489.

65 Usp. Ivo Ćurin, „Splitski posadni bataljon“, Split u narodnooslobodilačkoj borbi i socijalističkoj revoluciji $1941 .-1945$. (ur. Miroslav Ćurin), Split 1981., 632.

66 Poznato je pismo, koje iz perspektive suvremenika na upečatljiv način govori o kratkotrajnoj ustaškoj vlasti u Splitu. „Dragi Jure, kad ste vi, odnosno ustaška vlast poslije talijanskog zuluma i kaosa Narodno oslobodilačkog odbora, od rujna lanjske godine došli amo, vi ste imali mogućnost da se taktičnim ustupcima i pametnim radom dobro afirmirate“, napisao je anonimni splitski antifašist, vjerojatno komunist, u pismu koje je u drugoj polovini 1944. uputio svom poznaniku, ustaškom velikom županu u Splitu, Jurju Stanojeviću. Nadalje se u pismu ističe da veliki župan i ustaše u tadašnjem Splitu nisu imali gotovo nikakvu političku potporu, osim „,nekoliko, ali vrlo malo mlađih pristaša“ te skupine politički proračunatih pojedinaca koji su vrlo brzo počeli napuštati ustaški politički brod. U pismu se naglašava kako su ustaše „bili gori od Talijana“ jer nisu riješili glavni i najvažniji problem tadašnjeg Splita - opskrbu hranom. Obrazlažući svoju tvrdnju, anonimni splitski antifašist tvrdi da su ustaše - umjesto da se ugledaju na Talijane koji su, usprkos tome što su „mučili narod i provodili politiku odnarođenja“, redovito dijelili hranu i nadzirali cijenu kruha - dali „slobodne ruke švercerima“ i „dopustili da stanovništvo izgladni“. Veliki župan Stanojević je odlukom partizanskog prijekog suda u studenom 1944. strijeljan kao ratni zločinac. Usp. Tihomir Rajčıć, „Pismo kao dijagnoza ustaškog pokreta“, Slobodna Dalmacija (Split), 14. 4. 2016., 22. 


\section{Split from April i94i to September i943: A Site of FAscist Repression and Anti-FAscist Resistance}

The topic of the article is Fascist repression and anti-fascist resistance in Split in the period from April 1941 to September 1943. WW II arrived in Split with an Italian air force raid on 6 April 1941. After the breakdown and occupation of the Kingdom of Yugoslavia, the so-called Treaties of Rome (18 May 1941) on the borders between the Independent State of Croatia (the "official" name of which in the Treaties was "Kingdom of Croatia") and Mussolini's Italy, stipulated that "the city of Split including its suburbs" became part of the Fascist Italy, as a seat of one of the three prefectures within the province named Governatorato di Dalmazia (Governatorate of Dalmatia), under the provincial administration (Governo della Dalmazia) seated in Zadar. For the residents of the Split prefecture (around 130,000 of them), in which ruthless Italianization was being carried out, the spring of 1941 was the beginning of surely the most traumatic period of the $20^{\text {th }}$ century. The available sources clearly show that throughout all the stages of the cataclysm of the war the majority of Split residents demonstrated a permanent anti-fascist commitment, which is evidenced by the large number of Split-born fallen combatants and victims of Fascist terror in World War II. The ruthless war waged in the territory of the former Kingdom of Yugoslavia was a multi-layered affair which involved many protagonists. The events in Split during the time of the bloodiest conflict in the history of humankind can be divided into two parts: the first part, from the beginning of the air bombardment to the capitulation of Italy on 8 September 1943, and the second part, from September 1943 to October 1944 and the retreat of German and Ustasha forces from the city. At the time of the capitulation of Italy, the strength of the National Liberation Movement in Split reaches its peak, which is evidenced by the disarming of the majority of the Bergamo division.

Key words: Split, 1941-1943, Italian occupation, Split prefecture, National Liberation Movement

\section{$\cos$}

\section{Literatura}

Nikola Anić, Antifašistička Hrvatska. Narodnooslobodilačka vojska i partizanski odredi Hrvatske 1941.-1945., Zagreb 2005.

Antifašistički Split. Ratna kronika 1941. - 1945. (ur. Marin Kuzmić i dr.), Split 2010.

Nikica BARIĆ, Ustaše na Jadranu. Uprava Nezavisne Države Hrvatske u jadranskoj Hrvatskoj nakon kapitulacije Kraljevine Italije, Zagreb 2012.

Francesco CaCCAMo - Luciano Monzali (ur.), L'occupazione italiana della Ingoslavia (1941-1943), Firenze 2008.

Michael Clodfelter, Warfare and Armed Conflicts. A Statistical Reference to Casualty and Other Figures, 1500-2000, Jefferson 2002.

Zdenko Cvrlje (ur.), Druga dalmatinska proleterska brigada, Split 1982.

Ivo ĆurIn, „Splitski posadni bataljon“, Split u narodnooslobodilačkoj borbi i socijalističkoj revoluciji 1941.-1945. (ur. Miroslav Ćurin), Split 1981., 631-661.

Miroslav Ćurin (ur.), Dalmatinci u Prvoj proleterskoj brigadi. Zbornik sjećanja i popis boraca iz Dalmacije, Split 1982. 
Miroslav Ćurin (ur.), Split u narodnooslobodilačkoj borbi i socijalističkoj revoluciji 1941.-1945., Split 1981.

Danilo Damjanović, Šesta dalmatinska brigada, Beograd 1969.

Stevo ĐurašKović, „Zaboravljeni hrvatski kozmopolit Bogdan Radica“, Dijalog povjesničara - istoričara 10 (ur. Hans-Georg Fleck i Igor Graovac), sv. 1, Zagreb 2007., 307-327.

Ivo Goldstein, Hrvatska povijest, Zagreb 2013.

Igor GraOvac, „Pregled sudjelovanja pojedinih grupa stanovništva Splita u NOB-u i socijalističkoj revoluciji 1941. godine“, Split u narodnooslobodilačkoj borbi i socijalističkoj revoluciji 1941.-1945. (ur. Miroslav Ćurin), Split 1981., 361-376.

Snježana Grković-Janović (prir.), Lujzin dnevnik. Dnevnički zapisi Lujze Janović-Wagner iz Drugog svjetskog rata, Zagreb 2008.

Eduard Gugenberger, Boten der Apokalypse. Visionäre des Dritten Reichs, Wien 2002.

Aleksandar JAKIR, „Die 7. SS-Freiwilligen-Gebirgs-Division 'Prinz Eugen’ in Dalmatien“, Nationalsozialismus und Regionalbewusstsein im östlichen Europa. Ideologie - Machtausbau - Beharrung (ur. Ingo Loose i Burkhard Olschowsky), München - Berlin 2016., 369-386.

Aleksandar JAKIR, „Rimski ugovori između NDH i Italije“, Rimski ugovori: Kraljevina Italija - Kraljevina Hrvatska (NDH), 18. svibnja 1941. (ur. Marin Kuzmić i Boris Vušković), Split 2016., $24-53$.

Ivan JeLIĆ, Komunistička partija Hrvatske 1937-1941, Zagreb 1972., 320.

Fikreta Jelić-Butić, Četnici u Hravtskoj 1941-1945, Zagreb 1986.

Duško KečKemet, Prošlost Splita, Split 2002.

Nada Kisıć-Kolanović, NDH i Italija. Političke veze i diplomatski odnosi, Zagreb 2001.

Birgit Kletzin, Europa aus Rasse und Raum. Die nationalsozialistische Idee der Neuen Ordnung, 2 sv., Münster 2000. - 2002.

Alexander Korb, Im Schatten des Weltkriegs. Massengewalt der Ustaša gegen Serben, Juden und Roma in Kroatien 1941-1945, Hamburg 2013.

Bogdan Krizman, Ante Pavelić i ustaše, Zagreb 1978.

Bogdan Krizman, NDH izmecu Hitlera i Mussolinija, Zagreb 1986.

Vicko Krstulović, Memoari jugoslovenskog revolucionera, tom 1: Na stazama partije, revolucije $i$ bratstva i jedinstva. 1905-1943., Beograd - Sarajevo - Zagreb 2012.

Sibe Kvesić, Dalmacija u Narodnooslobodilačkoj borbi, Zagreb 1960.

Jelena Markovina, Sistem talijanske fašističke vlasti u Splitu od 1941. do 1943. godine, Split 1981.

Jürgen МаттнӓUs - Frank Bajohr, The Political Diary of Alfred Rosenberg and the Onset of the Holocaust, Lanham 2015.

Mark Mazower, Hitler's Empire. Nazi Rule in Occupied Europe, London 2008.

Luciano Monzali, Antonio Tacconi e la comunita’ italiana di Spalato, Venezia 2007.

Rolf-Dieter MüLler, Der Zweite Weltkrieg, Darmstadt 2015.

Narodnooslobodilačka borba u Dalmaciji 1941-1945. Zbornik dokumenata (ur. Vinko Branica), knj. 1, Split 1981.; knj. 2, Split 1982.; knj. 4, Split 1983.; knj. 10, Split 1986.

Mirko Novović - Stevan Petković (ur.), Prva dalmatinska proleterska NOU brigada, Beograd 1986.

Richard Overy i dr. (ur.), Die „Neuordnung“ Europas. NS-Wirtschaftspolitik in den besetzten Gebieten, Berlin 1997.

Marin Pelaić, Split za vrijeme talijanske okupacije (1941. - 1943.), Split 2012.

Ernst Piper, Alfred Rosenberg. Hitlers Chefideologe, München 2005. 
Bogdan Radica, Agonija Europe. Razgovori i susreti, Zagreb 2006.

Tihomir RajČić, „Pismo kao dijagnoza ustaškog pokreta“, Slobodna Dalmacija (Split), 14. 4. 2016., 22.

Michael SALEWsKi, „Europa. Idee und Wirklichkeit in der nationalsozialistischen Weltanschauung und Praxis, Europas Mitte (ur. Otmar Franz), Göttingen 1987.

Mate ŠAlov, Četurta dalmatinska (splitska) brigada, Split 1980.

Jozo Tomasevich, Četnici u Drugom svjetskom ratu, Zagreb 1979.

Jozo Tomasevich, Rat i revolucija u Jugoslaviji 1941-1945. Okupacija i kolaboracija, Zagreb 2010.

Fabijan TRGo, „Split kao grad u realizaciji koncepcije općenarodnog oslobodilačkog rata“, Split u narodnooslobodilačkoj borbi i socijalističkoj revoluciji 1941.-1945. (ur. Miroslav Curin), Split 1981., 479-490.

Duško VečErina, Talijanski iredentizam, Zagreb 2001.

Robert K. Wittman - David Kinney, The Devil's Diary. Alfred Rosenberg and the Stolen Secrets of the Third Reich, New York 2016.

Zbornik dokumenta i podataka o Narodnooslobodilačkom ratu jugoslovenskih naroda. Tom IX. Dokumenti organizacija Komunisticke Partije (ur. Fabijan Trgo), knj. 1, Beograd 1961.

Zbornik dokumenta i podataka o Narodnooslobodilackom ratu jugoslovenskih naroda. Tom XII. Dokumenti jedinica, komandi i ustanova Kraljevine Italije (ur. Miloš Krstić), knj. 1, Beograd 1969.

Vladimir ŽERJAVIĆ, Opsesije i megalomanije oko Jasenovca i Bleiburga. Gubici stanovništva Jugoslavije u drugom svjetskom ratu, Zagreb 1992. 